3 Article-type: Article

4

5

9 John F. Dewey $^{1 *}$, Ian W. D. Dalziel ${ }^{2}$, R. John Reavy ${ }^{3}$, and Rob A. Strachan ${ }^{4}$

\section{The Neoproterozoic to Mid-Devonian evolution of Scotland: a review and unresolved issues.}

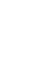

\author{
John F. Dewey², Ian W. D. Dalziel', R. John Reavy', and Rob A. Strachan
}

${ }^{1}$ University College, High Street, Oxford OX1 4BH, UK Austin TX 78758, USA

${ }^{3}$ School of Biological, Earth, and Environmental Sciences, University College Cork, Cork, Ireland

${ }^{4}$ School of Environmental Sciences, University of Portsmouth, Portsmouth, UK

*Correspondence (jfdewey@ucdavis.edu)

0 r/head: Tectonic evolution of Scottish Caledonides

2

Abstract: The purpose of this review paper is to identify and outline some critical questions

23 about the geology and tectonic evolution of the Scottish Caledonides in their wider

24 Caledonian/Appalachian context. We outline what we think we know and what we perceive to be 25 some important problems from about 1. 0 Ga (Grenville Orogeny) to Middle Devonian (Acadian 26 Orogeny). We do not attempt in-depth analyses of any terrain or tectonic topic in this review but, 7 mainly, pose questions. Scotland is considered in the context of the Irish Caledonides and the 28 Northern Appalachians, especially Newfoundland, so we make reference to these areas where 29 appropriate. Each section is intended as "stand-alone", not dependent upon prior or subsequent 30 sections; the sequence of sections, roughly in time order, has a historical narrative thread. We 31 have not included cross-sectional cartoons because we do not have a clear picture of plate

${ }^{2}$ Institute for Geophysics, Jackson School of Geosciences, The University of Texas at Austin, 
32 boundary zone and terrane arrangements in the Caledonides. There are too many enigmas,

33 paradoxes and unknowns to draw tectonic cross-sections with conviction.

34

35 Received 27 February 2014; revised 18 August 2014, accepted 21 August 2014

36 


\section{Introduction.}

40 Caledonia is the Latin name given by the Romans to the land inhabited by Celtic peoples lying

41 to the north of the outermost defenses of their province of Britannia, Hadrian's Wall from the

42 Solway Firth to the River Tyne and briefly Antonine's Wall from the Firth of Clyde to the Firth

43 of Forth. Suess (1906) referred to the Caledonian “pre-Devonian mountains” extending from

44 Scotland northeast to Norway and southwest to Wales and Ireland. Given the clear involvement

45 of Cambrian and Lower Ordovician strata in northwestern Scotland in tectonic events related to

46 the formation of the mountains, the Caledonian orogeny has long been regarded as an early

47 Palaeozoic event. Reviewing the historical background, and in the light of late $20^{\text {th }}$ Century

48 advances in the understanding and dating of Palaeozoic tectonic events, McKerrow et al. (2000)

49 redefined the Caledonian orogeny as embracing all Cambrian, Ordovician, Silurian and

50 Devonian tectonism associated with the development and closure "of those parts of the Iapetus

51 Ocean that were situated between Laurentia (to the NW) and Avalonia and Baltica (to the SE and

52 east)". Although recent work indicates that the South American portion of the Gondwanaland

53 supercontinent may also have been involved in the Taconic tectonism along strike in Laurentia

54 (Dalziel 2010), this definition reflects current usage.

56 The British Caledonides lie at the "triple junction” of three shields/platforms: the Laurentian

57 Shield, the Baltic Shield and Avalonia; and three orogens: the Greenland/Scandinavian

58 Caledonides, the Appalachians and the Polish Caledonides. The three orogens have partly shared

59 and partly different histories. The Greenland/Scandinavian orogen is, dominantly, a two-sided

60 mid-Silurian collisional system with major thrusting on both sides. The Appalachians are

61 dominated by Ordovician (Taconic) and mid-Devonian (Acadian) orogeny, have only a minor

62 development of Neoproterozoic rift seqences, and a sharp well-defined Cambro-Ordovician shelf

63 edge. The Polish Caledonides are the result of ocean closure between Avalonia and Baltica

64 during the Ordovician.

66 History of research on the Laurentian origin of the basement rocks of Scotland 
68 Modern marine and satellite geophysical data clearly demonstrate that the basement rocks of

69 northwestern Scotland were formerly adjacent to the margin of the North American continent.

70 Accurate palaeogeographic reconstruction prior to the opening of the North Atlantic Ocean

71 basin places the continental Rockall Bank and Scottish mainland adjacent to Greenland at the tip

72 of a promontory between the Caledonian orogen of East Greenland and the Appalachian orogen

73 of eastern Canada and the United States. This has been named the Scottish promontory (Dalziel

74 and Soper 2001) and Scottish corner (Leslie et al. 2008).

76 The North American affinities of the shelly fauna in the Cambrian and Lower Ordovician

77 platform cover of the Precambrian basement of the Northwest Highlands of Scotland were first

78 recognized by Salter in a contribution to an article on the succession of the older rocks there by

79 Murchison (1859), who drew attention to similarities in the preservation of these fossils and

80 specimens from limestone of the same age in Canada. Salter remarked: "That this truly North

81 American assemblage should be found in the extreme North of Scotland... and yet be scarcely

82 known further south, is at least suggestive of a geographic distribution...” A half-century later, in

83 the classic memoir on the geological structure of the north-west Highlands of Scotland (Peach et

84 al. 1907), Peach was able to state "Not only are the fossils identical on both sides of the Atlantic,

85 but the sediments in which they have been preserved present a remarkable similarity, as if the

86 North American and Scottish rocks were deposited under similar, if not identical, physical

87 conditions, and as part of one and the same geological and zoological province.” Subsequent

88 studies have confirmed that the Cambro-Ordovician sequence can be correlated formation by

89 formation to Newfoundland and NE Greenland (Cowie 1974; Smith \& Rasmussen 2008; Raine

90 \& Smith 2012). The Archaean and Paleoproterozoic crystalline basement of the northwest

91 Highlands and western isles fit well with that of the East Greenland region of Laurentia (Park

92 1994; Friend \& Kinny 2001). The continuation of the prominent Grenville province of present-

93 day eastern Laurentia into the western margin of Europe is still puzzling because only small

94 occurrences of $~ 1.0$ Ga Grenvillian rocks are known from western Ireland (Winchester and Max

95 1984; Daly \& Flowerdew 2005) and one locality in western Scotland (Sanders et al. 1984; Storey

96 2008).

97 
98 Cambrian fossils of Laurentian affinities have also been found adjacent to the Highland

99 Boundary Fault in the youngest part of the Dalradian Supergroup that forms the Grampian

100 Highlands, south of the Great Glen Fault. Limestones there contain both open-ocean miomerids

101 and polymerid shelf dwellers cons-specific with taxa in the allochthonous Quebec and New York

102 successions in the Ordovician Taconic orogen (Fletcher and Rushton 2007). Thus the Scottish

103 Highlands represent a fragment of the Laurentian continental margin. The basement and shelf

104 geology of Scotland records the history of this fragment while it was a part of Laurentia. This has

105 had implications for the development of geological thought. Prior to the understanding of

106 seafloor spreading and plate tectonics at about the time at which the Scottish Journal of Geology

107 was first published, the hypothesis of continental growth, or continental accretion, was widely

108 accepted in North America where Phanerozoic orogens surround a Precambrian core. However

109 the presence in northwest Scotland of a fragment of this ancient core, with some of the most

110 ancient Precambrian rocks in Europe, made this hypothesis less appealing to European

111 geologists.

112

113 We acknowledge the many legendary geologists and their achievements at a time when roads

114 and communication in the Scottish Caledonides were primitive. Horse, bicycle, and foot were the

115 only form of transport before the early $20^{\text {th }}$ century; topographic maps were made as the geology

116 was being mapped. James Hutton (1726-1797), the Scottish founder of geology, introduced the

117 concept of uniformitarianism on an ancient dynamic Earth. He recognized sedimentary strata as

118 evidence of a great repetitive cycle of sedimentation, uplift and erosion. At Siccar Point on the

119 Berwickshire coast of southeast Scotland, he described and evaluated the orthogonal

120 unconformity between vertical Silurian greywackes and sub-horizontal Devonian red-beds (Old

121 Red Sandstone). His masterpiece “Theory of the Earth” appeared in 1788 (Hutton 1788). John

122 Playfair (1748-1819) made Hutton's ideas more accessible in his "Illustrations of the Huttonian

123 theory of the Earth” (1802). John MacCulloch drew the first geological map of Scotland,

124 published in 1836, the year after his death. His map displays the main rock units of the and

125 clearly shows a great dislocation along the later-recognized Moine Thrust Zone (MacCulloch,

126 1840). Other important Victorian geologists, such as De la Beche, Sedgwick, and Lyell visited

127 and made much reference to Highland geology but did little original field work and observation

128 there. 


\section{Early controversies}

132 After MacCulloch, Scottish Highland geology became a focus of major controversy (Fig.1).

133 Murchison (1859), in his pursuit for the base of the Silurian System and stratigraphical

134 continuity, asseverated that there is a natural stratigraphic sequence from the Lewisian through

135 the Torridonian and Durness sequence into the Moine. In 1860, the young Archibald Geikie, a

136 acolyte of Murchison, walked along the Moine Thust Zone from Kinlochewe to Loch Broom

137 and pronounced that there is a natural sequence from the Lewisian into the Moine (Murchison

138 and Geikie, 1861) as averred by Murchison. This was a classic case of poor field work and a

139 desire to please the master. The authors have all, separately, repeated Geikie’s walk and marvel

140 at how a professional geologist could fail to recognize that gneisses (Lewisian) lie above a

141 gently-dipping contact with anchi-metamorphic sediments. However, Geikie’s sycophancy

142 worked in seeking high office and honours; he was appointed, in spite of indifferent scientific

143 contributions in the Highlands, to the Chair of Geology at Edinburgh, Directorship of the

144 Scottish Geological Survey, Directorship of the Geological Survey of Great Britain, and

145 achieved FRS, and knighthood. Nicol (1861) showed that there must be a major break across

146 what we now know as the Moine Thrust Zone. Nicol's correct intervention led to his being

147 denigrated and abused by the Murchison/Geikie camp. Luckily, in the late 1870’s, along came

148 James Callaway, who had done superb field work in Shropshire, Anglesey, and Donegal.

149 Mapping in the northern part of the “Assynt Bulge”, he showed that Lewisian high-grade rocks

150 are thrust, along what is now termed the Glencoul Thrust, across the imbricated low-grade

151 Durness sequence along a platy and lenticular zone in which the rocks are heavily deformed

152 (Callaway, 1883, 1884). Lapworth, arguably the greatest field-based geologist of all time, fresh

153 from his work in the Dobb’s Linn and other sections of the Southern Uplands, in which he

154 defined the Ordovician System and the basic structure of the Southern Uplands, began to map the

155 Eriboll area in the late 1870’s. He demonstrated, by exquisite and meticulous, fine-scale

156 mapping, that Moine rocks are thrust over the imbricated Durness sequence (Lapworth, 1883).

157 Lapworth was greatly influenced by Albert Heim who had just demonstrated major overthrusting

158 in the Swiss Alps. Lapworth’s beautiful field sheets and field notebooks, recently re-discovered

159 by Paul Smith in the Lapworth Museum in Birmingham, represent a milestone in the history of 
160 Scottish geology. Callaway's and Lapworth’s conclusions of major overthrusting in the Moine

161 thrust zone were well-known by 1880 before they published. They were of course, anathema to

162 Geikie, who now had the authority, as Director of the Geological Survey of Great Britain, to

163 assemble a team of his finest geologists to, once and for all, map the Moine Thrust Zone in the

164 Assynt region to demonstrate the correctness of the Murchison/Geikie continuous sequence

165 view. The team included Peach, Horne, Clough, Gunn, Hinxman, and Cadell, supported by Teall

166 as petrographer. They started mapping in 1881; within a few months, they showed,

167 unequivocally, that Callaway and Lapworth were correct in their view that the Moine Thrust

168 Zone exists as a major low-angle dislocation. Soon, another travesty ensued, highlighted by

169 papers in Nature by Peach and Horne (1884), and Geikie (1884) announcing the discovery of the

170 Moine Thrust and coining the term "thrust” with scant reference to Nicol, Callaway, and

171 Lapworth. Lapworth (1885) summarized his position and coined the phrase "The Highland

172 Controversy”. Nevertheless, the superb mapping of Peach, Horne, Clough, and their Survey

173 colleagues culminated in, perhaps, the finest publication in the field of geology, the 1907 British

174 Geological Survey Memoir on the "Geological Structure of the North-west Highlands of

175 Scotland”(Peach et al. 1907). The time line for the actors and events in this great Scottish

176 Victorian/Edwardian geological drama is summarized in Figure 1. The Highland Controversy is

177 analyzed in great detail in Oldroyd (1990).

178

179 In the 1950's, another unpleasant feud developed in the Northwest Highlands. Within the Moine

180 rocks of Knoydart, Glenelg, and Morar, hornblende-gneissic rocks occur as slivers and more

181 extensive areas beneath the Morar Division of the Moine Supergroup. W. Q. Kennedy (1955)

182 mapped and regarded these as Lewisian basement "inliers", whereas the Imperial College school,

183 led by John Sutton, considered them to be, following H. H. Read, 'Durcha Moine’, an

184 amphibolite-facies variant of the Moine in Sutherland. At an extraordinarily vituperative and

185 regrettable meeting of the Geological Society of London, Kennedy’s ground-breaking paper on

186 "The structure of Morar” was ridiculed in the discussion by a succession of Imperial College

187 speakers. Kennedy was subsequently proved right, later supported by the superb mapping of the

188 Knoydart Peninsular by John Spring (Spring 1960), an Imperial College Ph.D student. Kennedy

189 (e.g., 1964) turned his attention to the geology of the African continent. The Imperial College

190 group never published a retraction or publicly acknowledged their mistake but the situation was 
191 partly remedied by Ramsay and Spring (1962) and Poole and Spring (1974) in their papers on the

192 Knoydart/Morar Lewisan inliers and in a sentence in the Royal Society Biographical Memoir of

193 Kennedy (Sutton 1980). Parenthetically, in his Morar paper, Kennedy (1955), seemingly casually

194 but correctly, recognized that the age of the main deformation of the Highlands occurred in the

195 early Ordovician. Kennedy was, like Lapworth, a great scientist and polymath. He recognized

196 the Great Glen Fault (Kennedy,1946) as a major strike-slip fault, and worked and published

197 highly-original papers on a huge range of topics mainly in Scottish and African geology.

The basement, major structure, and events.

Figure 2 is a simplified summary tectonic map of Scotland and Ireland north of the Iapetus Suture. Traditionally, the 'basement' rocks of Scotland have been defined as the Archaean to

203 Palaeoproterozoic Lewisian Complex (Sutton and Watson 1951) of the northwestern coastal

204 region and the Western Isles, unconformably overlain by late Mesoproterozoic to

205 Neoproterozoic Torridonian strata (Park 1992). To the east, above the Moine Thrust, the meta-

206 sedimentary Moine "Supergroup”, forming most of the Northern Highlands northwest of the

207 Great Glen Fault, is unconformable on a gneissic basement, exposed in inliers. Some of these

208 basement inlier rocks have yielded Neoarchaean U-Pb zircon protolith ages (Friend et al. 2008),

209 confirming a Lewisian origin. Their subsequent tectono-metamorphic history before the

210 deposition of the Moine cover is uncertain, although the basement inlier of eastern Glenelg was

211 subjected to eclogite-facies metamorphism at about 1.0 Ga (Sanders et al. 1984; Brewer et al.

212 2003). A permissible model is that both Dalradian and Moine are underlain by a Neoarchean or

213 Palaeoproterozoic basement with a Grenville 1.0 Ga overprint. This is supported/permitted by

214 several lines of evidence. First, an uconformable contact is seen, in Co Mayo, western Ireland,

215 between the Palaeoproterozoic Annagh Head Gneiss Complex (Winchester and Max 1984) and

216 the Inishkea Division of the Dalradian Supergroup (McAteer et al. 2010a); the Annagh Head

217 Gneiss was overprinted and intruded by granite at about 1.0 Ga (Kennedy and Menuge 1992).

218 Second, the eastern Glenelg Lewisian basement has a "Grenville” overprint (Sanders et al. 1984;

219 Brewer et al. 2003). Third, on the Bullard et al. (1965) reconstruction of the North Atlantic

220 continents, the wide Grenville Province of Canada strikes directly towards the British

221 Caledonides. Fourth, in the Newfoundland Appalachians, in direct strike-continuity with the Irish 
222 Caledonides, Grenville rocks form the basement of both the Cambro-Ordovician Laurentian

223 Shelf but also are suspected, from the isotope geochemistry of Ordovician arc systems, to lie

224 beneath the arc(s) (Zagorevski et al. 2007). The Grenville Orogen consists mostly of older

225 basement provinces transected by the Grenville Front. Perhaps the Grenville Front, after

226 transecting the Ketilidian west of Ireland passes along the future line of the Great Glen Fault to

227 become the ancestral Moine Thrust zone with a multiple history. However, the exact

228 configuration of the Torridonian and Moinian basins, which has been debated since the $19^{\text {th }}$

229 Century (e.g. Geikie 1893), remains obscure because they are separated by the Caledonian

230 Moine thrust zone that carried the Moine over the basement rocks of the northwest foreland.

231 Geochronometric and other geochemical studies (discussed below) have revealed that the Moine

232 rocks were subjected to Neoproterozoic rift, intrusive and orogenic events along the margin of

233 Laurentia prior to the opening of the Iapetus Ocean basin. Hence, they are also, at least partially,

234 a part of the pre-Caledonian basement of Scotland, although the Neoproterozoic orogen was

235 overprinted by Caledonian deformation and metamorphism and intruded by Caledonian

236 granitoids. The Dalradian Supergroup, forming the Grampian Highlands to the southeast of the

237 Great Glen Fault, rests, at least locally, on a Moine-like metasedimentary base, although the

238 nature of the contact is unclear (Smith 1999; Leslie et al. 2008). The age of the base of the

239 Dalradian is also uncertain; this succession was not affected by Neoproterozoic orogenic

240 events. Hence, the Dalradian is not part of the Caledonian basement, and its basal strata are

241 likely to be younger than $\sim 750-700$ Ma.

243 We consider the Scottish and Irish Caledonides in six zones: (i) the Northwest Foreland with a

244 Lewisian basement inliers, (ii) the Northwest Highlands consisting of the Moine Supergroup

245 with Lewisianoid basement inliers and a Grenville overprint, (iii) the Colonsay/Islay Zone with a

246 Ketilidian basement, (iv) the Grampian Highlands with a problable Grenvillean basement, (v) the

247 Midland Valley with an uncertain basement and (vi) the late Ordovician to Wenlock Southern

248 Uplands accretionary prism. These zones are bounded by six major boundaries, the Moine Thrust

249 Zone, the Great Glen Fault, the Highland Boundary Fault, the Southern Uplands Fault, and the

250 Iapetus Suture Zone. We do not describe the basic detailed geology of the zones and their

251 boundaries, which can be found in many publications such as the Geology of Scotland, (Trewin

252 2002). Rather, we outline the salient facts that define problems. 
254 It is now clear that Ordovician (Grampian) deformation and metamorphism was widespread

255 across the Highlands between the Moine Thrust and the Highland Boundary Fault. The

256 Grampian Orogeny (Taconic Orogeny in the Appalachians) resulted from the collision of an

257 oceanic arc(s) with the Laurentian margin (Nelson \& Casey 1979; Dewey 2005), the timing and

258 events of which, with special reference to western Ireland are summarized in Figure 3. The

259 Wenlockian Scandian event, resulting from the Greenland/Baltica continent/continent collision,

260 affected only the Northwest Highlands. This suggests (Dewey \& Strachan 2003) that the

261 Grampian Highlands were at least $500 \mathrm{~km}$ to the southwest with respect to the Northwest

262 Highlands in the Silurian to avoid the Greenland/Baltica collision, a displacement that must have

263 been taken up along the Great Glen Fault. The northward continuation of the Great Glen Fault

264 probably passes through Shetland and Spitzbergen. To the south, its continuation into the

265 Appalachians is unclear, although the dextral White Bay-Deer Lake Fault Zone is a likely

266 candidate (Williams and Stevens 1974).

268 The Colonsay/Islay “Block” is enigmatic; the Dalradian Supergroup with its Ordovician

269 Grampian deformation and metamorphism is thrusted westwards across the Bowmore Sandstone

270 along the Loch Skerrols Thrust. The Bowmore feldspathic sandstone is mostly little-deformed

271 and of unknown age and affinity but possibly the last southwest remnant of the Moine (McAteer

272 2010b). To the west of the Loch Gruinart Fault, the four kilometer-thick Colonsay Group rests,

273 with tectonic contact, upon a 1.7 Ga syenite-gneiss basement (Muir et al. 1994; McAteer et al.

274 2010c) probably contiguous with the Ketilidian of southern Greenland. The non-volcanic

275 Colonsay succession consists of quartzites, feldspathic sandstones, pelites and minor carbonates

276 mostly at greenschist-facies with a polyphase deformation sequence that varies greatly in

277 intensity from strongly-lineated quartzites to dark phyllites. McAteer et al. (2010c) suggested

278 that Colonsay Group belongs to a Grenville foreland basin, with which we concur. They also

279 suggested that the detrital zircon population is similar to the lower Dalradian. We suggest that

280 this correlation is unlikely: if the Colonsay Group is part of a Grenville foreland basin, the

281 Dalradian must be at least 300 my. younger than the Colonsay Group. Many of the Colonsay

282 Group psammites are micaceous on cleavage, whose white micas could be Ar/Ar dated;

283 combined with high-resolution-heavy-mineral-analysis, these correlations could be tested. 
285 The Moine and probably the Dalradian are underlain by a basement, possibly Lewisian and

286 Ketilidian remobilized at about 1.0 Ga (Fig. 2), that was hyper-extended during the long-drawn-

287 out late Pre-Cambrian continental rifting events that preceded the opening of Iapetus at about

288550 Ma (Henderson et al. 2009), similar to the situation in Newfoundland (Van Staal et al.

289 2013). The basement beneath the Midland Valley is arcane with several conceivable origins

290 including basement under-thrusting as discussed below. The Southern Uplands is a southward-

291 thinning subduction-accretion greywacke wedge. It's northern $30 \mathrm{~km}$ crust was built by the

292 rotation and vertical thickening of accreted greywacke prisms above the subducted northern

293 Skiddaw toe of the Lake District.

295 The orogenies and their boundary zones

297 The general model (Dewey 1969, Dewey and Shackleton 1984) for the evolution of the northern

298 Appalachians and the Scottish and Irish orthotectonic Caledonides involves the collision of the

299 Laurentian rifted margin with an oceanic arc system and other terranes; and the obduction of

300 fore-arc ophiolites (Dewey \& Casey 2011; 2013), the Bay of Islands and Shetland Ophiolite

301 Complexes onto the rifted margin, followed by a flip in subduction polarity (Nelson \& Casey

302 1997) and the development of a south-facing arc and accretionary prism (Southern Uplands and

303 South Connemara; Ryan \& Dewey 2004; Dewey 2005). The supposed line or zone of arc-

304 continent collision runs from South Achill and Clew Bay ('Clew Bay Line’) in western Ireland

305 (Chew et al. 2003), through Co. Tyrone, and along the Highland Boundary Fault to Shetland

306 (Fig. 2). It is marked, discontinuously, by dismembered ophiolites, rifted margin serpentinites,

307 fragments of accretionary prisms and blueschists (Chew 2003; Chew et al. 2003; Dewey \&

308 Mange 1999; Gray and Yardley 1979; Henderson and Robertson 1982; Henderson et al. 2009;

309 Yardley 1980; Yardley and Senior 1982). The devil is in the details, however; the reality is much

310 more complicated. The continental Ox Mountains and possibly the Midland Valley Terranes are

311 of unclear provenance, although they have Laurentian affinity. The Ballantrae Ophiolite

312 Complex was obducted onto the southern margin of the Midland Valley Terrane whereas the

313 Shetland (Flinn 1958) and Bay of Islands complexes (Dewey \& Casey 2011; 2013) were

314 obducted onto the Grampian Terrane and Laurentian foreland respectively. The Grampian 
315 Orogeny was accomplished during dextral transpression (Dewey 2005), the Erian and Scandian

316 phases during sinistral transpression (Soper et al. 1992), the early Devonian during sinistral

317 transtension (Dewey \& Strachan, 2003) and the Acadian during north-south shortening.

319 We consider the gross shape of the basin(s) in which the Moine was deposited to be well-

320 constrained. From its maximum extent in the Northwest Highlands, it narrows to the northeast

321 and south west (Fig. 2). In Islay, if the Moine is present, it is represented only by the Bowmore

322 Sandstone, a weakly-deformed feldspathic arenite in a zone some $10 \mathrm{kms}$ wide between the Loch

323 Skerrols Thrust, which puts the Dalradian westwards across the Bowmore Sandstone, and the

324 Loch Gruinart Fault, west of which lie the Ketilidian-age Rhinns Complex basement and

325 Colonsay Group cover (Muir et al. 1994; McAteer et al.2010c). In Shetland, the obducted

326 Unst/Fetlar Ophiolite and its underlying Dalradian sequence has a very narrow zone of Moine-

327 like rocks, and crystalline basement to the west. Thus, in Islay and Shetland, the Moine is

328 reduced to a narrow constricted zone between the Dalradian and northwest foreland basement. In

329 western Ireland, the Inishkea Division of the Dalradian rests unconformably upon the Grenville

330 Annagh Head Gneisses (Kennedy and Menuge 1992), between which the Moine is no longer

331 present. The Moine and Torridonian are completely absent in the northern Appalachian orogen

332 but the Torridonian may be represented in the Van Horn Sandstone Group in Trans-Pecos Texas

333 (Davidson 1980).

336 Orogenic history of the Moine Supergroup

338 The Moine Supergroup became internationally important through the seminal studies, during the 339 1950’s, of Gilbert Wilson and John Ramsay who unraveled the complex fold patterns that

340 became used in many undergraduate textbooks as type examples of polyphase deformation

341 (Wilson 1953, Ramsay 1957; 1960; 1962). At that time, because the Moine rocks were involved

342 together with the Cambrian and Ordovician strata of the Durness succession in tectonism along

343 the Moine thrust belt, this complex deformation (and metamorphic) history was regarded as

344 entirely Caledonian. However, as a result of over 50 years of geochronological investigations

345 coupled with detailed structural and metamorphic analysis, the current consensus is that Moine 
346 rocks were affected also by Neoproterozoic orogenesis . The history of these investigations is

347 highly instructive in showing how thinking has evolved in the interpretation of high-grade

348 metamorphic complexes, and also how analytical techniques have evolved to the current position

349 where significant insights into the evolution of an orogenic belt can be obtained by study of a

350 single thin section.

351

352 The first evidence that the complex deformation histories of the Moine rocks might relate to

353 more than one orogenic event came from the first Rb-Sr age-determinations of minerals and

354 whole rocks from the Scottish Highlands by Giletti et al. (1961). In addition to evidence for

355 widespread Caledonian metamorphism (420 $\pm 15 \mathrm{Ma}$ ), ages of c. 740 and c. 665 Ma were

356 obtained for muscovite books in pegmatites from Knoydart and Morar discovered by Kennedy et

357 al. (1943). Giletti et al. (1961) concluded that: “a Pre-Cambrian event must be responsible for

358 the formation of the pegmatites”. Rb-Sr and K-Ar mineral ages of c. 700-740 Ma obtained by

359 Lambert and Long (1963) and Lambert (1969) from metasedimentary rocks and pegmatites in

360 the Morar-Knoydart area and Carn Gorm (Fig. 4) confirmed this conclusion. The implicitly

361 orogenic event resulting in these late Precambrian ages was referred to as either the Knoydartian

362 (Bowes 1968) or Morarian (Lambert 1969). Knoydartian is now the more commonly used name.

364 Further complexity was introduced by Rb-Sr whole rock ages of c. 1100-1000 Ma obtained from

365 the West Highland granitic gneiss and the Morar Pelite (Brook et al. 1976; 1977). These ages

366 were thought to record peak metamorphism during the Grenville orogeny, suggesting a pre-1100

367 age of deposition for the Moine sediments. Further work by van Breemen et al. (1974; 1978) and

368 Piasecki \& van Breemen (1983) produced additional Rb-Sr and U-Pb mineral ages of c. 700-800

369 Ma and there was much debate as to whether the Moine rocks had been affected by separate

370 Grenville and Knoydartian orogenic events or that the c.700-800 Ma isotopic ages were the

371 result of incomplete resetting of older ages during the Caledonian orogeny. Early U-Pb zircon

372 and monazite data were commonly discordant and difficult to interpret with confidence. It was

373 only with the advent of more sophisticated dating techniques, that this debate was resolved.

375 The ability to analyse single grains of accessory minerals such as zircon and monazite using U-

$376 \mathrm{~Pb}$ isotopes has revolutionized the study of seemingly intractable metamorphic complexes. A key 
377 target for the first modern geochronological investigation of Moine rocks was the granitic gneiss 378 of western Ardgour, the southernmost body of the West Highland Granite Gneiss (Fig. 2). This 379 had been interpreted by Dalziel (1966) to have resulted from more or less in situ melting of its 380 host Moine rocks during regional, high-grade metamorphism (Barr et al.1985). The U-Pb zircon

381 age of $873 \pm 7$ Ma (Friend et al. 1997) was interpreted as dating this high-grade event because the 382 dated grains were obtained from a migmatitic layer within the granitic gneiss. Older Proterozoic 383 ages, mostly from 1800-1000 Ma, were obtained from 'inherited' zircon grains in the Moine 384 sedimentary protolith of the granite gneiss. This clearly indicated a post-Grenville age of 385 sedimentation for the Moine rocks, a conclusion substantiated by further studies of 386 inherited/detrital zircons in Moine rocks elsewhere (Kinny et al. 1999; Friend et al. 2003; 387 Cawood et al. 2004; Kirkland et al. 2008). The Rb-Sr whole rock ages of c. 1100-1000 Ma 388 referred to above (Brook et al. 1976, 1977) were shown to be of uncertain significance.

390 The significance of the c. 870 Ma age for the Ardgour granitic gneiss was, however, rapidly 391 questioned. Did it represent the age of a high-grade metamorphic (implicitly orogenic) event or 392 the age of a pre-tectonic protolith to the gneiss? Dalziel and Johnson (1963) and Soper \& Harris 393 (1997) argued, from structural evidence, that the emplacement of the granitic protoliths of the

394 various members of the West Highland Granite Gneiss suite occurred prior to the earliest 395 deformation event within its host Moine rocks. This view was further developed by Millar 396 (1999) and Dalziel and Soper (2001) who suggested an extensional origin for both the granite 397 protolith and a suite of nearly synchronous mafic sheets cutting it and dated at 873 \pm 6 Ma at Glen 398 Doe by Millar (1999, U-Pb zircon). Recently, a reliable U-Pb date has been determined for 399 zircon from the Sgurr Dhomhnuill augen-rich facies of the Ardgour granite gneiss north of 400 Strontian. This rock does not have the migmatitic appearance of the gneiss elsewhere and is 401 likely to represent the protolith with deformed feldspar phenocrysts. A U-Pb zircon age of 863 \pm 7 402 (Cawood et al. in review) reinforces the interpretation that the granitic protolith of the gneiss and 403 the mafic sheets were intruded during the same extensional event at that time.

405 Other U-Pb studies yielded results that substantiated the original concept of a c. 700-800 406 Knoydartian orogeny. U-Pb monazite data for pegmatites in Morar and the Ardnish Peninsula 407 gave ages of $827 \pm 2$ and $784 \pm 1$ Ma respectively; structural studies suggested that they were 
408 generated synchronously with localized high- temperature shearing and garnet-grade

409 metamorphism (Rogers et al. 1998). Moreover, Sm-Nd systematics of garnets in the Moine rocks

410 of Morar indicated that growth occurred during the interval 820-790 Ma at $650-700^{\circ} \mathrm{C}$ and $11-12$

411 kbar, suggesting substantial crustal thickening (Vance et al. 1998).

413 Dalziel and Soper (2001) developed their extensional model for the origin of the West Highland

414 Granite Gneiss and associated mafic sheets by proposing that the same interpretation could also

415 be applied to the Precambrian pegmatites within the Moine rocks. They regarded the garnet ages

416 and related PT work of Vance et al. (1998) to be of uncertain significance. Their extensional

417 model carried the implication that orogenic deformation and metamorphism of the Moine rocks

418 occurred entirely during the Caledonian orogeny. They suggested that the Knoydartian extension

419 and a later phase of granitic intrusion that generated the protolith of the Carn Chuinneag-Inchbae

420 granite and augen gneiss of the Northern Highlands at c. 600 Ma were related to the initial break-

421 up of the Rodinian supercontinent and the incipient formation of the Iapetus Ocean basin

422 respectively.

424 Resolution of the debate resulted from the realization that the only reliable way of distinguishing

425 between shortening and extensional structures, developed in mid-crustal metamorphic regimes, is

426 by examining the pressure-temperature evolution of isotopically-dated mineral assemblages. This

427 approach has provided evidence for at least three Neoproterozoic orogenic events in Northern

428 Scotland. The oldest of these is dated at c. $930 \mathrm{Ma}$ and has so far only been recognized in the

429 Westing Group metasedimentary rocks of Unst in the Shetland Islands (Cutts et al. 2010). PT

430 conditions deduced for this event are c. $650^{\circ} \mathrm{C}$ and 8-9 kb. Detailed analysis of Glenfinnan

431 Group (?) rocks in the Glen Urquhart area (Fig. 4), confirmed c. 825-780 Ma growth of garnet

432 at $650^{\circ} \mathrm{C}$ and $7 \mathrm{~kb}$ (Cutts et al. 2010), consistent with the results of Vance et al. (1998) in the

433 Morar area. A second stage of garnet growth at Glen Urquhart occurred at $724 \pm$ Ma on a P-T

434 path rising to $700^{\circ} \mathrm{C}$ and $\sim 9.0 \mathrm{~kb}$ with the peak conditions associated with partial melting. This

435 was consistent with the U-Pb age of $737 \pm 5$ Ma obtained from titanite (sphene) in the Lochailort

436 area (Tanner \& Evans, 2003), the two studies providing independent evidence for a distinctly

437 younger Knoydartian event at c.725-735 Ma. 
439 It now appears, therefore, that the Neoproterozoic history of northern Scotland involved 1) an 440 orogenic event at c. $930 \mathrm{Ma}$; 2) an extensional phase with granite and mafic sheet emplacement 441 at 870-860 Ma; 3) compressional 'Knoydartian’ orogenic phases at 825-780 Ma and 725-735

442 Ma; 4) c. 590 Ma intrusion and extension related to the opening of Iapetus (i.e. Inchbae Granite 443 gneiss). In most areas, these are only represented by the earliest folds and porphyroblasts because 444 of extensive ductile reworking and overprinting in Ordovician and Silurian times by Caledonian 445 orogenesis (Kinny et al. 1999; 2003a; 2003b; Rogers et al. 2001; Strachan \& Evans 2008; Alsop 446 et al. 2010). A major problem remains the correlation of the various phases of deformation 447 observed in the field throughout the Moine outcrop (e.g. Ramsay 1963; Powell 1974) with these 448 metamorphic events, particularly as there are now more metamorphic events identified than sets 449 of fold structures in most areas (Cawood et al. in press). There is no known orogenic

450 unconformity, obvious margins to these events, and no obvious way to identify this break of over 451200 my between the Knoydartian and Caledonian events in the field. Regionally significant 452 structures such as the Sgurr Beag Thrust (Fig 2) may have a Knoydartian and Caledonian history, 453 and some major folds may be composite (Bird et al. 2013).

455 Neoproterozoic orogenic events are widespread in the southern continents and some of the 456 orogens mark the sutures along which the Gondwanaland supercontinent was assembled in 'Pan457 African’ continent-continent collisions (Kennedy 1964). As pointed out by Dalziel and Soper 458 (2001), they are not known in North America. However, they are found in the Laurentian 459 Caledonides of East Greenland and Svalbard, as well as within the Laurentian-derived 460 allochthons of Norway (Daly et al. 1991; Leslie et al. 2008; Kirkland et al. 2011). Metamorphic 461 events dated at >950 Ma in East Greenland and Svalbard were thought to correspond to a 462 northern arm of the Grenville orogeny (Park 1992; Lorenz et al. 2012). Explanation of 463 significantly younger 800-700 Ma Knoydartian events in Scotland was more difficult to explain 464 as most palaeo-continental reconstructions placed Baltica directly opposite East Greenland, and 465 Scotland therefore occupied a position well within the Rodinia supercontinent (Dalziel \& Soper 466 2001). One solution is that these shortening and crustal-thickening events were intra-cratonic, 467 perhaps comparable with the Peterman orogen in central Australia (Cawood et al. 2004; Dewey 468 2005). However, more recent supercontinent reconstructions have placed Baltica significantly 469 further south of East Greenland (Cawood \& Pisarevsky 2006; Li et al. 2008), meaning that 
470 Scotland would have been situated along the edge of Rodinia, close to the 'Asgard Ocean'.

471 Cawood et al. (2010) reconstructed the Neoproterozoic "Valhalla" accretionary orogen from the

472 Moine in mainland Scotland, and broadly correlative successions in Shetland, East Greenland,

473 Svalbard and Norway. It is notable that the reconstruction of the Valhalla orogen in the present

474 northernmost part of Laurentia is spatially compatible with the collision of present southern

475 Laurentia with the Kalahari craton at 1000 Ma (Loewy et al. 2011; Fig. 5).

477 Tectonostratigraphic issues in the Northern Highlands

479 A long-lived controversy in Scottish geology is the extent to which the Torridonian and Moine

480 are lateral equivalents, with differing opinions expressed by Ben Peach and his Survey

481 colleagues (Peach et al. 1907). Constraints on the age of sedimentation of the two successions

482 are relatively poor. The Torridon Group is somewhere within the Neoproterozoic by the c. 1000

483 Ma ages of the youngest detrital minerals and the Cambrian age of unconformably overlying

484 sedimentary rocks. None-the-less, the most reasonable interpretation of palaeomagnetic data and

485 isotopic data from shales thought to date diagenesis indicates probable deposition at c. 990-1000

486 Ma (Turnbull et al. 1996; Stewart 2002). The Morar Group rocks are only marginally better

487 constrained by the youngest detrital zircon age of $980 \pm 4$ Ma (Peters et al. 2001) and the 820

488 Ma age of the oldest Knoydartian metamorphic event. Slight differences in the relative

489 proportions of different age groups of detrital zircons led Friend et al. (2003) and Cawood et al.

490 (2007) to believe that the Torridon and Morar groups were deposited in different basins, but

491 these could simply result from relatively few data sets. Krabbendam et al. (2008) argued, on

492 general geological grounds, that the simplest solution is that the two are coeval fluvial to shallow

493 marine successions that were deposited just after c. $1000 \mathrm{Ma}$ in a foreland successor basin to a

494 southerly Grenville orogen. This theme was pursued by Bonsor et al. (2012) who proposed

495 tentative correlations between various units of the Torridon and Morar groups in northern Ross-

496 shire. The reality or otherwise of such correlations is an important research question that could

497 be addressed by further, much more detailed, studies of detrital mineral suites as a potential

498 means of linkage across the Moine Thrust Zone. 
500 The age of deposition of the Morar Group and whether or not it correlates with the Torridon

501 Group has further ramifications for the status of the Moine rocks as a 'Supergroup'. The tripartite

502 division of the Moine rocks into Morar, Glenfinnan and Loch Eil ‘divisions’ (Johnstone et al.

503 1969; Johnstone 1975) was superceded by the proposal that these divisions have the status of

504 groups; from that arose the concept of a Moine Supergroup (Roberts et al. 1987; Holdsworth et

505 al. 1994). For this to be valid, the boundaries between constituent groups have to be

506 stratigraphic. Although the Morar-Glenfinnan contact is defined by the Sgurr Beag Thrust on the

507 mainland, this does not appear to be the case on the Ross of Mull where it was interpreted as

508 stratigraphic (Holdsworth et al. 1987). The Glenfinnan-Loch Eil contact was similarly shown to

509 be stratigraphic elsewhere (Dalziel 1966; Roberts and Harris 1983). However, recent U-Pb

510 dating of detrital zircons from the Glenfinnan Group at Glen Urquhart has important

511 implications. The youngest zircon ages are $908 \pm 8 \mathrm{Ma}$ and $917 \pm 13 \mathrm{Ma}$, which represent a

512 lower age limit for sedimentation (Cutts et al. 2010). This dataset poses the question: is the

513 Morar Group also younger than 920-900 Ma? Cawood et al. (2010) identified two major cycles

514 of sedimentation and orogenic activity within the Neoproterozoic rocks of the North Atlantic

515 borderlands. The older successions were affected by ‘Renlandian’ orogenic activity at 930-920

516 Ma, and this was followed by a further cycle of sedimentation in post-900 Ma successor basins

517 that were later affected by Knoydartian events 820 Ma onwards. The Glenfinnan and Loch Eil

518 Groups fall within the latter category. The central question is whether the Morar Group is part of

519 the same package and not, therefore, correlative with the Torridon Group, or is it distinctly older

520 than the Glenfinnan-Loch Eil succession? If the latter, the Morar-Glenfinnan contact on the Ross

521 of Mull may hide a cryptic sedimentary break. Does this also correspond to an orogenic

522 unconformity between Morar Group rocks affected by 930-920 Ma tectonic activity and a

523 younger Glenfinnan Group?

524

525 Northwest Foreland and Moine Thrust Zone: comparisons with the Appalachians

527 The Eriboll through Durness sequence of the Northwest Foreland is part of a Cambro-

528 Ordovician continental shelf along the margin of Laurentia from Alabama to northeast

529 Greenland (Dewey 1969). It is also found in the Cuayania terrane in northwestern Argentina that

530 originated in the Ouachita embayment south of Alabama (Dalziel \& Soper 2001) (Fig. 5). The 
531 Assynt Culmination beneath the Moine Thrust is the finest repository of superbly-exposed

532 orogenic thrust margins in the world and has been superbly mapped by generations of geologists

533 (e.g. Coward 1985; British Geological Survey 2007). West of the Moine Thrust is the Lewisian

534 crystalline basement, recording Neoarchean (3000 - 2700 Ma) to Palaeoproterozoic (2000 - 1670

535 Ma) igneous, metamorphic and tectonic events (Park et al. 2002; Friend \& Kinny 2001;

536 Goodenough et al. 2013). East of the Moine Thrust, basement to the Moine may be Lewisian

537 remobilized at about 1.0 Ga during the Grenville Orogeny, whose foreland basin may be the

538 Colonsay succession of Islay and Colonsay (McAteer et al. 2010c). We speculate that the Moine

539 Thrust Zone has had a long history as the Grenville Front, a Moine basin-bounding extensional

540 zone, possibly the Knoydartian, the boundary of Grampian deformation (hence termination of

541 Durness carbonate deposition in the early Ordovician), and the Scandian orogenic front in the

542 mid-Silurian.

543

544 In the Appalachians, especially in New England and Newfoundland, the shelf edge to the Iapetus

545 Ocean is delineated precisely and sharply by an abrupt Cambro-Ordovician facies change from

546 shallow marine strata to continental slope and rise clastic sediments (Williams and Stevens

547 1974), although the continental rise was a hyper-extended margin with Grenville basement (Van

548 Staal et al. 2013). This margin was destroyed and its rift-phase Fleur-de-Lys sediments were

549 deformed and metamorphosed to, locally, eclogite facies by the obduction of the Bay of Islands

550 Ophiolite Complex, the fore-arc to the Lushs Bight Arc. Beneath the Ophiolite Complex, a

551 turbidite (Goose Tickle) foreland basin was generated during the Taconic (Grampian) orogeny in

552 early to mid-Ordovician times (Williams and Hiscott 1987). The westward movement of and

553 loading by Bay of Islands Ophiolite Complex generated a peripheral bulge disconformity

554 beneath the Table Head base of the Goose Tickle foreland basin (Bird \& Dewey 1970). This

555 clear sharp, rifted, continental margin destroyed by arc-continent collision is not evident in

556 northwest Scotland in the Moine Thrust Zone. Here, early Llanvirnian cessation of carbonate

557 deposition in the Durine Formation of the Durness Group led Kennedy (1955) to the prescient

558 conclusion that major orogeny began in the Highlands in early Ordovician times. The equivalent

559 of the Goose Tickle foreland basin and ophiolite obduction is absent or, at least, has not been

560 preserved in the Scottish Highlands. We speculate that Grampian ophiolite obduction and the

561 consequent foreland basin did not develop in Scotland because of the very wide Proterozoic rift 
562 complexes that confined Grampian ophiolite obduction to a very narrow zone along the Clew 563 Bay/Fair Head/Highland Boundary Fault Zone (e.g. Tanner 2007). Major ophiolite obduction

564 across the Highlands, as envisaged by Dewey and Shackleton (1984) is difficult to demonstrate

565 and an arc-continent bulldozing mechanism might be sought for the Grampian Orogeny in

566 Scotland and Ireland.

567

568 The final displacement along the Moine Thrust Zone (Elliot and Johnson 1980) is of Silurian (c, $569430 \mathrm{Ma}$ ) age as demonstrated by the precise U-Pb zircon dating of broadly syntectonic igneous 570 suites in the Assynt area (Goodenough et al. 2011) and their structural relationships (Searle et al. 571 2010). Whether there are sets of structures that relate to earlier displacements (e.g. Grampian, 572 and/or Mayoian, see below) will be uncertain until the precise extent and margins of

573 Knoydartian, Grampian, and Scandian structures in the Moine is known and further radiometric

574 dating of fabrics along the Moine, Glencoul, Benmore, and other thrusts, are undertaken,

575 However, as Kennedy (1955) pointed out, the youngest strata to have been involved in the Moine

576 Thrust Zone are the early Ordovician (Llanvirn) Durine Member of the Durness Limestone,

577 which strongly suggests that the Grampian Orogeny terminated deposition on the shelf The

578 oxidized Torridonian and anchi-metamorphic Cambro-Ordovician sequence indicates very low

579 temperatures below the Moine Thrust (e.g. Johnson et al. 1985) and suggest that the Moine

580 Nappe was thin west of the Sole Thrust and, therefore, with little more than $77 \mathrm{~km}$ displacement

581 (calculated from the Assynt Sheet, British Geological Survey 2007 ). Nevertheless, loading by

582 the Moine Nappe would surely have generated foreland basins unless the Lithosphere were

583 thinned and weakened for which there is no obvious evidence such as major magmatic

584 outbreaks. The powerful basement thrusting and imbrication in the Assynt Culmination does not

585 indicate, we suggest, a weak crust and thinner Lithosphere but the thrust detachment of the tops

586 of post Torridonian/pre-Eriboll normal fault blocks (Soper and England 1995). The Lewisian

587 basement had been last affected by the late-Laxfordian event at c. 1650 Ma (Friend \& Kinny

588 2001) and, therefore, would have had substantial flexural strength. Hence, any foreland basin

589 would have been small amplitude/long wavelength and easily removed (eg. Larson et al. 1999).

590 The Cambro-Ordovician shelf sequence shows no sign of sudden thinning and/or facies change

591 eastwards; its eastern limit is unknown. It did not cover the Dalradian because the coeval early

592 Ordovician McDuff Slates and the middle Cambrian Leny Limestone are in deeper water facies. 
594 Therefore, although the basic plate tectonic model for the Cambro-Ordovician evolution of the

595 Caledonides and Northern Appalachians is that of an oceanic island arc complex colliding with

596 the Laurentian margin (Nelson \& Casey 1979), there are substantial differences. In the

597 Appalachians, the arc collided with a very sharp rifted margin with the obduction of fore-arc

598 ophiolites across narrow poorly-developed rift complexes onto the Laurentian foreland and

599 loading of the margin to develop foreland basins (Dewey \& Casey 2013). In the Scottish and

600 Irish Caledonides, the arc collided with a much wider, more diffuse, and longer -lived rifted

601 margin with less or no ophiolite obduction, and bull-dozing by the arc, perhaps similar to

602 Taiwan.

603

604

605 The Dalradian, Grampian, Highland Boundary Fault, and Midland Valley

607 The Dalradian Supergroup lies in a block bounded by the Great Glen and Highland Boundary

608 Faults (Fig.2), and moved by at least $500 \mathrm{~km}$ into its position relative to the Moine between 428

609 and $385 \mathrm{Ma}$ at a minimum average rate of about $11.6 \mathrm{~mm} / \mathrm{a}$ (Dewey \& Strachan 2003). That the

610 Dalradian "belongs" to the Laurentian margin of Iapetus is show by its North American fauna

611 (Fletcher and Rushton 2007; Stubblefield 1956), its broad stratigraphic similarity with late

612 Neoproterozoic sequences in East Greenland and Newfoundland and its Laurentian sources as

613 seen in detrital zircon populations (Cawood et al. 2003).

614

615 The stratigraphy of the Dalradian is very well-defined (Anderton 1982; Harris et al. 1994;

616 Strachan et al. 2002; Stephenson \& Gould 1995) with the Port Askaig Tillite sequence

617 (Marinoan glaciation, c. $635 \mathrm{Ma}$ ) a key time-rock marker (e.g. Brasier \& Shields 2000). The

618 Dalradian is mostly shallow marine and deposited in extensional basins but the highest, South

619 Highland Group strata are mostly deep-water greywackes and pelites, a large part of which must

620 be Cambrian-lower Ordovician (Molyneux 1998; Tanner 2011). This latter sequence begins with

621 the Tayvallich Formation mafic volcanics at c. 600 Ma (Halliday et al. 1989) roughly equivalent

622 to the Lighthouse Cove Basalts of Newfoundland (Williams \& Hiscott 1987), a sequence

623 representing accelerated Lithospheric thinning heralding the opening of Iapetus between 
624 Laurentia and the Andean margin of South America. The bulk of the deformation and

625 metamorphism of the Dalradian Supergroup is early to mid-Ordovician (Grampian; Dewey \&

626 Mange 1999).

628 The structure, although well-documented (Thomas 1979; Treagus 1987), is less understood. The 629 dominant structure is the southeast-facing, and probably southeast-verging, Tay Nappe with its 630 downward -facing nose along the Highland Border (Shackleton 1958; Krabbendam et al. 1997;

631 Tanner 2013), and the Loch Awe Syncline to the northwest. In Connemara, major D2/D3 fold 632 nappes face northwards consistent with models that involve collision of an oceanic arc with and 633 overthrusting onto the Laurentian margin (Dewey 2005). However to the north of Clew Bay, the 634 nappes of North Mayo face to the southeast (Chew 2003). The Tay Nappe is enigmatic in that it 635 faces to the southeast. Four possible reasons are: 1. That the nappe was gravitationally-driven by 636 spreading and/or sliding from a Loch Awe zwischengebirge high, 2. That the Tay Nappe is a 637 retrocharriage backfold of the top limb of a north-verging D1 nappe, 3. That the Midland Valley 638 Terrane underthrust the Grampian Highlands directly beneath and caused the Tay Nappe, 4. 639 That the Tay Nappe was a large south-verging fold above a north-dipping subduction zone, or 5. 640 That the Midland Valley Terrane formed a wedge that separated the Dalradian from its 641 basement, thus, simultaneously, generating the Tay Nappe and a basement to the Midland 642 Valley. This wedge model is similar to the crustal delamination model Waschbusch et al. (1998 ) 643 for the South Island of New Zealand; a Tasman wedge is driving eastwards along the Moho of 644 the South Island separating the crust, which passes through a monocline to form the Southern 645 Alps, and the mantle, which is subducting beneath the Tasman Sea.

647 Two key points emerge; first, that simple plate tectonic cross-sectional solutions cannot be 648 applied along the length of the Caledonian/Appalachian Belt or any mountain range and, second, 649 that the existence of a basement or presumed basement must not be taken to mean that the 650 basement was, necessarily, the foundation for the development of rock systems above. However, 651 it is possible that the Midland Valley has an "autochthonous” basement; if so, the Midland 652 Valley may have been a micro-continent with a small ocean between it and the Dalradian margin 653 that closed along the Highland Boundary Fault Zone; a problem with this interpretation is that 654 there is no evidence of subduction-related magmatism in the Midland Valley or in the Highlands 
655 prior to the mid-Silurian. Clearly, oceanic Lithosphere must have existed along the Highland 656 Boundary Fault Zone because the Zone contains Ordovician ophiolites (Bute, Shetland), which 657 have a fore-arc affinity. Sheared serpentinized lherzolites with sheeted carbonates and gabbro 658 slices probably represent sub-continental mantle beneath an extensional detachment along the 659 original margin of Iapetus. These sub-continental mantle rocks are known also in western Ireland 660 along the Clew Bay suture zone (Chew 2001; Kennedy 1980) and in the Baie Verte Suture Zone 661 in Newfoundland (Bursnall 1973: Van Staal et al. 2013) where they mark the Laurentian margin 662 of Iapetus against which an oceanic arc collided during the early Ordovician (Nelson \& Casey 663 1979). These lherzolitic associations are common in the Swiss Alps (Malenco/Platta Nappe) and 664 in the Sestri-Voltaggio zone of the Ligurides of Italy where they represent sub-continental 665 mantle tectonically denuded at a magma-poor rifted margin during Jurassic extension to generate 666 para-oceans (Manatschal \& Muntener 2009). How then to evaluate the tectonic role of the 667 Highland Boundary Fault? The presence of rifted (early Cambrian) margin sub-continental 668 mantle rocks (Henderson et al. 2009) and earliest Ordovician fore-arc ophiolites indicates that an 669 arc collided with a rifted margin. By analogy with western Ireland and Newfoundland, the arc 670 faced and collided with the Laurentian margin during the early Ordovician (Dewey 2005) but, 671 unlike Newfoundland, its fore-arc ophiolites did not obduct very far, if at all, onto the rifted 672 margin Rather, we suggest, the arc bulldozed the Laurentian margin to cause the Grampian 673 Orogeny, a very short-lived event followed by subduction polarity flip to initiate a trench on the 674 south side of the South Connemara/Southern Uplands accretionary prism (Ryan \& Dewey 2004) 675 . Although the Midland Valley and the South Mayo Trough appear to be parts of the same 676 terrane (Fig. 2), there are clear and significant differences. The South Mayo Trough was the fore677 arc of an oceanic island arc until about $477 \mathrm{Ma}$ in the early Arenig when the arc magmas became 678 contaminated by the subduction of Laurentian margin sediments to generate a silicic arc 679 immediately prior to collision (Draut \& Clift 2001). The obduction of the hot arc onto the 680 Laurentian margin is believed to have generated the north-verging nappes and account for the 681 Barrovian metamorphism of the Dalradian rocks of Connemara. In contrast, the Midland Valley 682 may have, in part, a Pre-Cambrian basement (Aftalion et al. 1984: Upton, et al. 1976) and there 683 is no clear evidence for an Ordovician arc. However, Badenszki et al. (2011) have shown, from 684 Carboniferous diatreme xenoliths, that zircons may have been derived from an 685 Ordovician/Silurian arc. The tectonic provenance and significance of the Midland Valley 
686 Terrane is obscure; it may be an Ordovician arc with continental basement fragments or it may 687 be, partially, the equivalent of the Ox Mountains Terrane in Ireland. The Ballantrae Ophiolite 688 Complex is on the southern margin of the Midland Valley and, although it has a subduction 689 metamorphic sole, subjacent rocks are not seen (e.g. Stone 2014a). The Midland Valley Silurian 690 shallow marine to fluviatile sediments can be interpreted as a fore-arc basin north of the 691 Southern Uplands accretionary prism. In the South Mayo Trough, the Silurian fore-arc basin 692 contains andesitic detritus and a diorite sill, establishing its arc credentials above a north-dipping 693 subduction zone (Dewey 2005).

695 In Banffshire, the greenschist/epidote amphibolite Upper Dalradian succession sits in a broad 696 synclinorium, bounded to the west by a major extensional detachment zone (top down to the 697 east) from Portsoy in the north to at least the southwest margin of the Morven-Cabrach Gabbro 698 (Viete et al. 2010). The low-grade hanging wall contains the classic mafic/ultramafic intrusions 699 of Insch, Haddo House, and Huntly, above the subjacent higher-grade footwall to the west. The 700 mafic/ultramafic intrusions are tholeiitic, in contrast to the calc-alkaline mafic/ultramafic 701 intrusions of Connemara but both were intruded during the Grampian deformation sequence. To 702 the southeast of the Banff Syncline all major structures, including the Tay Nappe and the Banff

703 hanging wall of the Portsoy Detachment, verge to the southeast. We do not understand the origin 704 of this dominant southeast vergence beyond that it involves a massive southeastward translation 705 of the upper part of the Grampian structural pile (Krabbendam et al. 1997; Tanner 2013).

707 In Connemara, a strong case can be made for relating the Barrovian metamorphism to the 708 northward obduction of a hot oceanic arc across the Laurentian margin with the injection of 709 calc-alkaline mafic/ultramafic mamas from the arc into the evolving, north-verging D2/D3 710 nappes (Wellings 1998). It is difficult to ascribe the Barrovian metamorphism of Scotland to

711 such a mechanism because the major folds face to the south-east, across the classic Barrovian 712 zones.

714 The Highland Boundary Fault Zone drops Devonian strata against the Highland Border 715 downward-facing down-bend. Its straightness has led to the notion that it must be a large716 displacement strike-slip fault. However, Tanner (2011) has adduced cogent evidence that 
717 sinistral post-Silurian strike-slip cannot be large (tens of kilometres) and must be Ordovician

718 perhaps of the same age as the sinistral motion that emplaced the Connemara Terrane to the

719 South of the South Mayo Trough.

\section{Mayoian.}

723 The Mayoian phase of shortening somewhere between 460 Ma and $443 \mathrm{Ma}$ is an enigmatic

724 feature of the Scottish and Irish Caledonides (Fig.3) and the western Appalachians of

725 Newfoundland (the Salinic). Steve Temperly has, on many informal occasions and discussions at

726 meetings, drawn attention to this orogenic phase and its regional importance. We call it Mayoian

727 from its clear and strong expression in the South Mayo Trough, where Llandoverian strata rest

728 unconformably upon early Ordovician rocks on the northern and southern sides of the Trough,

729 cutting out several thousands of metres of Ordovician strata that are preserved within the Trough

730 (Dewey 1963). The pre-Late Llandovery detachment and docking of the Connemara Dalradian

731 Terrane may be Mayoian (Dewey 2005). The Mayoian is also expressed by shortening structures

732 in the Moine (Bird et al. 2013) and Dalradian (Chew \& Strachan 2013). The Highland Border

733 downbend (Shackleton,1958) may be Mayoian We do not understand the origin of this

734 shortening but speculate that it may have been the result of subduction slab flattening, like the

735 current Pampean Ranges of Argentina and the Laramide Orogeny in the western United States.

736 The Mayoian affects both Moine and Daradian Terranes; it is arc-related because the Moine and

737 Dalradian were not juxtaposed until after the Scandian collision.

\section{Southern Uplands}

741 The Ordovician and Silurian rocks of the Southern Uplands (Fig.6) constitute one of the World's

742 finest examples of an extinct subduction-accretion wedge (Dewey 1971; Leggett et al. 1979;

743 Stone 1995; 2014b). The Midland Valley Terrane, to the north, is a fragment of, possibly, Neo-

744 Proterozoic Lithosphere and/or Ordovician arc that was overthrust northwards by the Ballantrae

745 Ophiolite Complex in the early Llanvirn. The Ballantrae Complex was covered by a shallow

746 marine Caradoc sequence, which shows that it could not have been the source of the Portpatrick

747 blue-schist detritus (Kelling 1961). Ordovician rocks between the Southern Upland Fault and the 
748 Glen App Fault represent the zone of subduction polarity flip, to northward subduction from

749 South Connemara to Scotland that was the harbinger of the South Connemara, Southern

750 Uplands and Longford-Down accretionary prism (Ryan \& Dewey 2004). That the Southern

751 Uplands are an accretionary prism is demonstrated by the southward-younging diachroneity of

752 both the onset and cessation of turbidite (trench facies) sedimentation (Fig. 6 and Stone 2014b) .

753 Between the Glen App Fault and the Carghidown sequence, the turbidite facies succeeds the

754 Moffat Shale (oceanic facies). From the Carghidown seqence to the Iapetus Suture, the turbidite

755 facies has no exposed Moffatt Shale substrate. We take this to mean that, at the Kirkmaiden

756 seqence, (M. crispus zone), the suduction interface switched from the shale/basalt contact to the

757 base of the greywackes, possibly induced by the thinned northern edge of the Lake District

758 Terrane beginning to underthrust the Southern Uplands accretionary prism. Tight collision

759 between the Southern Upland accretionary prism and the Lake District was in M. lundgreni

760 times (c. $424 \mathrm{Ma}$ ) when the first debris of Southern Upland origin arrived in the Lake District

761 (Soper \& Woodcock 2003). The gentle northward dip of the base of the accretionary prism above

762 the subducted northern margin of the Lake district can be seen on the WINCH seismic reflection

763 profile (Hall et al. 1984).

764

765 Subduction-accretion began in N. gracilis times at about $456 \mathrm{Ma}$ and progressed southwards until

766 M. lundgreni times at about 424 Ma (Fig. 6) when the Southern Uplands collided with the Lake

767 District to cause the Erian phase of deformation. Southward progression of subduction-accretion

768 of about $5.14 \mathrm{~mm} / \mathrm{a}$ is expressed perfectly with the onset and cessation of turbidite deposition in

769 greywacke packages of about 1.2 my (roughly the same length as a graptolite zone) above

770 oceanic dark shales, (Fig. 6).

772 The extent of end-Silurian Erian deformation in relation to southward-younging subduction-

773 accretion deformation in the Southern Uplands is not yet clear (Stone et al. 1997). In the

774 Ordovician-Silurian South Mayo Trough in western Ireland, Erian sinistral transpression (Soper

775 et al. 1992) is recorded in a very complex sequence of anchimetamorphic to greenschist -facies

776 structures, and was the result of very oblique (less than $20^{\circ}$ ) closure of the Iapetus suture close to

777 the Silurian/Devonian boundary. The regional clockwise-oblique cleavage of the Southern

778 Uplands (Stringer and Treagus 1980) suggests, at least partly, Erian sinistral transpression. 
780 Detrital heavy minerals in the Southern Uplands (Kelling 1961; Mange et al. 2005) record the

781 Caradoc to Wenlock (c. 458 - $423 \mathrm{Ma}$ ) erosion of an obucted ophiolite complex and the

782 Dalradian metamorphic complex. That the Southern Uplands are a subduction-accretion prism

783 and not a collisional foreland basin is indicated by the black shales of zones 2 to 8 (e.g. Moffat

784 Shale) and their subjacent mafic volcanics in the Leadhills Group (Fig. 6; Stone 2014b). A

785 difficult problem has been the source of sediments of the Southern Uplands. Kelling (1961) was

786 the first to characterize the detrital heavy mineral assemblages across the Rhinns of Galloway.

787 Mange et al. (2005) conducted a comprehensive survey of heavy minerals assemblages across

788 the Southern Uplands; Grampian metamorphic and Laurentian detritus is dominant throughout

789 with ophiolitic, glaucophane and lawsonite detritus in the Portpatrick Formation. Clearly, the

790 Grampian metamorphic complex, the Laurentian basement, and an obducted ophiolite complex

791 were sourcing the subduction-accretion prism but the source of the higher pressure blueschist

792 minerals is not clear. The low-grade assemblage of the Ballantrae Ophiolite Complex is an

793 unlikely source for the lawsonite. Alternatively, lawsonite is recorded in the Cadomian blueschist

794 complex of Anglesey. Stone and Evans (2001) have recorded Cadomian-age zircons in the

795 Southern Uplands but Waldron et al. (2008; 2014) have shown that the zircons were sourced,

796 probably, from igneous sources associated with rifting of the Laurentian margin, not from

797 Avalonia.

798

799

$800 \quad$ Newer granites

801 The Siluro-Devonian granite suite (the Newer Granites, Fig. 7) is the last major “cratonizing”

802 event in Scotland. Late Pre-Cambrian/early Cambrian granites such as the Ben Vurich and the

803 alkaline Inchbae-Carn Chuinneag bodies are probably related to continental stretching

804 immediately before the opening of Iapetus and will not be considered here. Caledonian plutonic

805 activity in Britain and Ireland occurred during two main episodes, the 470-460 Ma Grampian

806 Orogenic event and the 447-383 Ma granitoids that were emplaced during and after the final

807 closure of the Iapetus Ocean. Read (1961) named these two intrusive suites the "Older Granites"

808 and "Newer" Granites. The Newer Granites of the British and Irish Caledonides (Fig. 7) have

809 the appearance of a bottle of red ink splashed across the map; they intrude almost all zones of the 
810 orthotectonic and paratectonic Caledonides (Dewey 1969) with a wide variety of I- and S- types

811 (Chappell \& White 1974; 2001). A quick reminder: I-type granites have a meta-igneous source,

812 are generally higher-temperature, higher- $\mathrm{Na}_{2} \mathrm{O}$, oxidized (magnetite-bearing; Ishihara 1977)),

813 and hornblende-bearing, commonly with mafic enclaves and co-mingling relationships, whereas

814 S-types are partial melts of meta-sediments, reduced (ilmenite-bearing; Ishihara 1977)), higher-

$815 \mathrm{~K}_{2} \mathrm{O}$ and alumina, and garnet and/or cordierite-bearing, commonly with meta-sediment enclaves.

816 The Newer Granites have been studied intensively over many decades and much classic and

817 pioneering work has been done, such as on the Donegal batholith (Pitcher \& Berger 1972;

818 Hutton 1982; Stevenson 2008; Stevenson et al. 2008). Despite this, there remain many

819 unresolved issues. Some are typical of granites irrespective of age or setting such as the perennial

820 protolith debate about crustal and mantle sources and the relative proportions and significance of

821 contribution from different reservoirs (Chappell 1996); this debate feeds into the origin and

822 development of the continental crust, whether by recycling of existing crust by partial melting or

823 by addition of new crustal material with a significant mantle component. This (Chappell \&

824 White 1974; 2001) is largely a geochemical and isotopic discussion, ubiquitous to granites

825 worldwide, and the reader is referred to Stephens and Halliday (1984), Atherton and Ghani

826 (2002), Fowler et al. (2001, 2008), and Neilson et al. (2009).

827 The fundamental problem of Caledonian granites is that they were generated and emplaced over

828 a long time, and emplaced into extremely heterolithic crust across an orogen that was involved in

829 multiple amalgamation and accretion events during the complex collisions of Baltica, Laurentia

830 and Avalonia as the Iapetus Ocean closed, and in subsequent post-closure tectonics. No single

831 tectonic model for magma genesis explains the genesis and evolution of the Newer Granites.

832 However, using an array of relevant multidisciplinary techniques, major advances have been

833 made recently. The plutons were emplaced over $67 \mathrm{My}$ (447 Ma to $380 \mathrm{Ma}$ ) during the Scandian

834 Orogeny, the docking of Laurentia and Avalonia, late Caledonian sinistral transcurrent lock-up

835 (Hutton and Reavy 1992) and the Acadian Orogeny (Woodcock et al. 2007). They are present in

836 all terranes north of the Iapetus. We first outline the petrological aspects of the intrusions and

837 suites in different terranes, assess gross similarities, and highlight major unresolved problems. 
838 The vast majority of the Newer Granites in Scotland and NW-Ireland are I-type (sensu lato), 839 taken, here, to indicate crustal melting with a possible, small, mantle contribution. This differs 840 from the original definition (Chappell \& White 1974), which underplayed or ignored mantle

841 involvement. Such intrusions typically show a broad range of lithologies from diorite/quartz

842 diorite through granodiorite to granite. They are, commonly, composite with internal contacts

843 (Cruden et al. 1999); if these contacts are absent, they are normally-zoned, generally more

844 primitive/mafic at the margins or, less commonly, reversely-zoned. Coeval mafic enclaves are

845 very common especially in the diorite/granodioritic components. Associated appinite suites

846 range in composition from ultramafic to intermediate, have euhedral hornblende, are commonly

847 very coarse grained/pegmatitic. and commonly occur in diatremic pipe-like forms. They are

848 taken, generally, to represent evidence of an enriched mantle origin and are intimately linked to

849 granitoid genesis. Some workers have argued that these magmas are involved in crustal

850 underplating and/or crustal melting (Stephens \& Halliday 1984) or argued that fractionation of

851 such compositions was a significant process in granite generation (Fowler et al. 2008). In the

852 Grampian Terrane, intrusions such as Ballachulish, Etive, Rannoch Moor, Strath Ossian, Foyers

853 and Ross of Mull, Strontian, Cluanie, Rogart, Helmsdale and Strath Halladale in the eastern

854 Northern Highlands are I-type.

855 There are significant regional departures, such as the trend to more syenitic and alkaline

856 compositions towards the north-west in the North-west Highlands (Fowler et al. 2008;

857 Goodenough et al. 2011). Ratagain is transitional between the normal I-types and the more 858 alkaline types. Glen Dessarry is syenitic and the complexes in the far NW are extremely alkaline;

859 Loch Ailsh and Loch Loyal are quartz-bearing syenites whereas Loch Borralan is the only 860 nepheline syenite in the UK (Parsons 1979).

861 In southern Scotland, several intrusions in the Southern Uplands (Cairnsmore of Fleet and 862 Criffell) are S-type and several of the plutons in Aberdeenshire (Cairngorm and Peterhead) are 863 more A-type in character. The suite concept (White \& Chappell 1983; Chappell 1996), based on 864 their petrography and composition, may reflect the involvement of different protoliths.

865 Stephens \& Halliday (1984) first distinguished the Argyll, South of Scotland and Cairngorm 866 Suites (Fig. 7) south of the Great Glen; the first two suites are, dominantly, I-type. Hornblende is 
867 characteristic of diorites in the Argyll Suite, and associated appinites are abundant.

868 Geochemically, this suite is typified by very high abundances of Sr and Ba and low abundances

869 of $\mathrm{Nb}$, Th and $\mathrm{Rb}$. This $\mathrm{Sr}$ and Ba enrichment was attributed to enriched mantle fluids that

870 initiated lower crustal melting to generate I-type magmas, although Fowler et al. (2008)

871 proposed that similar characteristics in intrusions NW of the Great Glen could be the result of

872 small volume-assimilation products of mantle-derived appinitic magmas. The South of Scotland

873 suite (Stephens \& Halliday 1984) includes Garabal Hill, Comrie and Arrochar in the southern

874 Highlands, Glen Tilt and Glen Doll in the north-east Highlands and other bodies in the Midland

875 Valley and Southern Uplands. Although generally I-type, this suite is has pyroxene-rich diorites

876 and low Ba and Sr contents. Cairnsmore of Fleet and Criffell have S-type characteristics. The

877 Cairngorm suite consists of red-biotite granites some of which have A-type affinities; in contrast

878 to the other suites, they have high trace element abundances of $\mathrm{Nb}, \mathrm{Rb}$ and $\mathrm{Th}$ and low

879 abundances of $\mathrm{Ba}$ and Sr. In Ireland, the Donegal granites, which were emplaced into the along-

880 strike equivalent of the Grampian Terrane, are also broadly I-type with abundant appinites;

881 therefore, it is possible that they could be assigned to the Argyll suite. However, the Newry

882 Complex, which lies within the Longford-Down Massif, is I-type but is along strike from S-type

883 plutons in the Southern Uplands.

884 Stone et al. (1997) noted a distinction based on geochemical and isotopic characteristics between 885 granites north and south of the Moniaive Shear Zone, and the associated Orlock Bridge Fault, 886 suggesting that this reflects a compositional break in the crust at this structure. North of the 887 Orlock Bridge Fault, intrusions are older (c. $410 \mathrm{Ma}$ ) whereas intrusions to the south are, 888 typically, younger (c. $395 \mathrm{Ma}$ ). They highlighted the $\mathrm{Pb}$ isotope similarities between granitoids 889 of the Lake District and those south of the Orlock Bridge Fault, previously noted by Harmon \& 890 Halliday (1980) and Thirlwall et al. (1989), expanding their synthesis into an Avalonian terrane.

891 I-type granites to the north and S-types to the south of the Orlock Bridge Fault with

892 chronological and geochemical differences suggest different petrogenetic mechanisms for each

893 group (see Atherton \& Ghani 2002; Brown et al. 2008; Neilson et al. 2009; Stone et al. 1997).

894 From this distinction, and following Brown et al. (2008), we define the Northern Granites, which 895 are those granites believed to be of Caledonian origin north of the Orlock Bridge Fault (this 896 grouping includes the three suites already recognized by Stephens \& Halliday (1984)) and the 
897 Trans-Suture Suite which includes those granitoids that are late Caledonian and sited south of the

898 Orlock Bridge Fault. However some Irish Granites, for reasons discussed below, do not fit easily 899 into either of these categories and they are grouped here as Unassigned Irish Granites.

900 Within the Northern Granites, consideration must be given to the tectonic history of the

901 individual terrane. In the broadest terms, any granitoids that occur within the Northern Highlands

902 Terrane, and are between 467-425 Ma, are likely to be related to northward subduction and

903 Scandian collision between Laurentia and Baltica. All Newer Caledonian granites south of the

904 Great Glen Fault and north of the Orlock Bridge Fault are likely to be associated with the

905 accretionary processes involving Laurentia and Avalonia. Early models proposed that continued

906 subduction of the Iapetus Ocean crust beneath the Laurentian margin drove calc-alkaline

907 magmatism north of the Orlock Bridge Fault (Soper 1986). A suite of appinite and lamprophyre

908 dykes was synchronous with these granites (Rogers \& Dunning 1991; Atherton \& Ghani 2002;

909 Fowler et al. 2001; Macdonald \& Fettes 2007; Pitcher \& Berger 1972). From the association of

910 these minor intrusions with I-type granites, several authors suggested that magmatism was

911 caused by crustal melting initiated by hydrous mantle-derived magmas, driven by active

912 subduction of the Iapetus Ocean under the Laurentian Margin (Dewey 1971; Soper 1986;

913 Thirlwall 1988). Oliver et al. (2008) envisaged continental margin subduction analogous to the

914 Andean margin (Pitcher et al. 1982).

915 However, much of this magmatism cannot be related to active subduction because most granites

916 were emplaced well after subduction had ceased and collision had occurred (Pitcher 1982;

917 Neilson et al. 2009). Pitcher (1982) termed them “Caledonian I-types” to distinguish the Argyll

918 and Donegal granites from the Andean I-types.

919 Atherton \& Ghani (2002) proposed that collisional/post-collisional slab break-off could have

920 would have allowed the asthenosphere, at about $1,330^{\circ} \mathrm{C}$, to rise, impinge on, and melt the base

921 of the Lithospheric mantle to produce a lamprophyric under-plate with associated dykes and

922 appinite intrusion; high temperatures at the base of the Lithosphere may have melted this

923 underplate to produce the granites. This predicts a short peak in magmatism that would have

924 significantly postdated active subduction. This model is somewhat confusing because their

925 diagrams clearly relate to the Scandian convergence whereas many of the granites are in the 
926 Grampian Terrane and Donegal, which were then hundreds of kilometres south of the region that 927 experienced Scandian collision.

928 In the Northern Highlands, a problem is the petrogenesis of alkaline magmas within what was 929 first a subduction and then a collisional setting. Goodenough et al. (2011) have dated the

930 duration of the Scandian event; much of the magmatism is later than active subduction. The Glen

931 Dessarry Pluton (447 $\pm 2.9 \mathrm{Ma}$ ) pre-dates the formation of the early Scandian steep belt, and,

932 therefore, sets a lower limit to Scandian deformation. The late suite of the Loch Borralan Pluton

933 (429.2 $\pm 0.5 \mathrm{Ma}$ ) is roughly synchronous with (Searle et al. 2010) to just after Moine thrusting

934 (Goodenough et al. 2011) Scandian thrusting. Scandian shortening had, therefore, ceased by c.

$935430 \mathrm{Ma}$; the pulse of appinites and granites at $425 \mathrm{Ma}$ (Fowler et al. 2008) could be explained by

936 post-Scandian slab break off; at this time, orogen-parallel strike-slip motion began (Dewey \&

937 Strachan 2003).

938 In the Grampian Terrane, there is no evidence of subduction-related magmatism; the terrane

939 would have been several hundred kilometres north of the active trench. Neilson et al. (2009)

940 argued that the subduction of Avalonia beneath Laurentia would have been resisted by c. 430 Ma

941 and the supply of hydrated oceanic Lithosphere within a subduction system would have ceased.

942 New dating of granitoids, dykes and volcanics in south-west Argyllshire show that magmatism

943 continued for at least 25 Ma after subduction had ceased and was not defined by a single short

944 pulse as predicted by Atherton \& Ghani (2002). Neilson et al. (2009) envisage slab break-off and

945 the rise of hot asthenosphere to the base of the Lithosphere to melt and form appinitic and

946 lamprophyric magmas. Because of the large volume of intermediate and felsic magmas

947 generated, Neilson et al. (2009) favour continual underplating and melting of mafic crust

948 representing substantial crustal recycling. They propose that this asthenospheric heat was

949 sufficient to drive magmatism for the subsequent c. $22 \mathrm{My}$.

950 In Ireland, no granites are attributed to Scandian orogenic processes. The age, tectonic setting 951 and geochemistry of the Donegal Granites (Stevenson et al. 2008) are consistent with the slab 952 break-off model of Atherton \& Ghani (2002) and Neilson et al. (2009). They are therefore 953 assigned to the Northern Granites. 
954 The Trans-Suture Suite of (Brown et al. 2008) includes all granitoids south of the Orlock Bridge

955 Fault. The Trans-Suture Suite is S-type; most plutons contain two mica granites; ages range

956 between c. 400-390 Ma. It includes the classic S-type Leinster Granite and the Isle of Man

957 granites. The Leinster Granite, the largest granitoid in the British Isles, clearly lies south of the

958 Orlock Bridge Fault. Because it is S-type and dated at 405 +/- 2 Ma (O’Connor et al. 1989), it is

959 assigned to the Trans-Suture suite. Detailed petrographic work has shown multiple mixing events

960 of batches of felsic compositions (Grogan \& Reavy 2002).

961 The Newry Igneous Complex (Fig.7), however, exhibits strong I-type affinities and ages of c.

962 420-410 Ma (Meighan et al. 2003). Although it lies south of the Orlock Bridge Fault, its age and

963 characteristics are more consistent with the Northern granitoids; it is therefore anomalous in the

964 context of the model proposed by Brown et al. (2008) and is grouped with other Unassigned

965 Granites.

966 Whereas all these trans-suture intrusions (excluding Newry) share some S-type affinities, Brown

967 et al. (2008) suggest that they are not S-type sensu stricto but that they tend towards this end

968 member compared with granites further north. In many cases, they are zoned with S-type

969 interiors and I-type outer margins and contain mafic enclaves throughout (e.g, the Criffell pluton

970 (Stephens 1992; Stephens \& Halliday 1984)). The Trans-Suture Suite was emplaced on both

971 sides of the Iapetus Suture, was coincident with Acadian orogenic deformation in Britain and

972 Ireland, and post-dates an episode of transtension that followed the Caledonian Orogeny between

973 410-400 Ma (Dewey \& Strachan 2003). These granitoids are closely associated with a

974 prominent porphyritic lamprophyre dyke swarm that extends from the Central Belt of the

975 Southern Uplands into eastern Ireland (Rock et al. 1986; Vaughan 1996).

976 Several models have been proposed for the Trans-Suture Suite; the key points include the clearly

977 younger age of these intrusions (c. 20-30 My after final Laurentian-Avalonian convergence),

978 their occurrence north and south of the Iapetus Suture, and their S-type chemistry, which reduces

979 the feasibility of models applicable to the Northern Suite (see Brown 1991; Soper 1986; Atherton

980 \& Ghani 2002). Magmatism driven by subduction of Iapetan and Avalonian Lithosphere or slab

981 break-off are not feasible because of the occurrence of granitoids south of the Iapetan Suture 
982 Zone. Orogenic crustal thickening, and/or decompression leading to melt generation are also

983 highly unlikely because magmatism continued for up to $40 \mathrm{My}$ after these processes terminated.

985 Brown et al. (2008) proposed that the extensive suite of lamprophyre dykes, generated during the 986 410-400 Ma period of transtension, advected heat through the Lithosphere thus driving melting

987 of the crust. The granitoids were of hybrid origin with overall S-type affinity but also containing 988 relatively primitive mafic components (e.g. Criffell). Mafic magmas charged with volatiles,

989 derived from partial melting of metasomatized sub-continental Lithospheric mantle, were 990 emplaced during Devonian transtension (Dewey \& Strachan 2003) and decompression, 991 promoting anatexis and upward propagation of melt. Brown et al. (2008) concluded that

992 continued migration of lamprophyric melt through the crust was responsible for crustal melt 993 generation during 410-400 Ma transtension and that emplacement of this magma in the mid to 994 shallow crust was achieved later during the Acadian Orogeny. A problem with this model is that 995 no magmatism was recorded in the Trans-Suture Suite during the period of transtension, which 996 was suggested as being responsible for magma genesis. One might expect a continuation of 997 plutonic activity throughout and shortly after the controlling tectonic event. Furthermore, the 998 model does not consider the role of the Rheic oceanic crust, which was being subducted beneath 999 the accreted Avalonian-Laurentian continent during genesis and emplacement of these granitoids 1000 (McCarthy 2013). Acadian deformation is recognised as early as 400 Ma (Sherlock et al. 2003; 1001 Woodcock et al. 2007); presumably subduction of Rheic Ocean Lithosphere was active at this 1002 time and earlier.

1003

1004 Several Irish granites belong neither to the Northern Granites or the Trans-Suture Suite. The 1005 Newry Granite problems have already been highlighted. The Siluro-Devonian Galway Granites 1006 are north of the OBF; the largest intrusion, the Main Batholith, straddles the Skird Rocks Fault 1007 (SRF) (either an extension of the Southern Uplands Fault (Feely et al. 2006; Leake 2006) or a 1008 southern splay of the Highland Boundary Fault (Ryan et al. 1995). The Galway Granites mostly 1009 meet the criteria for belonging to the Northern Granites. They are all I-type (Feely et al. 2006), 1010 located north of the OBF, and most were emplaced between 425-405 Ma (Selby et al. 2004; 1011 Feely et al. 2007). They are, geochemically, similar to the Argyll Suite (Crowley 1997). The 1012 largest volumes of magma in Galway were emplaced between 402-397 Ma, the latest (Costelloe- 
1013 Murvey) is $380.1 \pm 5.5 \mathrm{Ma}$ (Feely et al. 2007; 2010). Therefore, the younger intrusions are

1014 temporally related to the Trans-Suture Suite but are tectonically out of place north of the OBF.

1015 The older intrusions (425-405 Ma) are consistent with models proposed for the Northern

1016 Granites but share a spatial and geochemical association with the younger intrusions and are

1017 unlikely to be petrogenetically distinct.

1018

1019 The most perplexing issue of the Galway granites is the broad spectrum of crystallisation ages in

1020 the batholith and surrounding plutons. The earliest date is in the Omey Pluton, which has a

1021 secondary molybenite age of $422.5 \pm 1.7 \mathrm{Ma}$ (Feely et al. 2007), implying that the granite predates

1022 this. The youngest crystallisation age is in a sample collected from the Main Batholith and yields

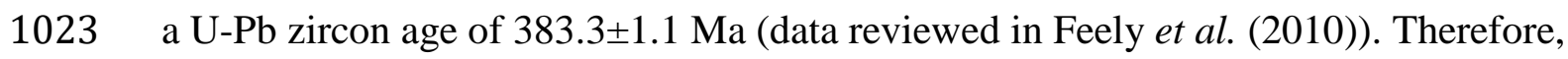

1024 magmatism extended for a minimum of c. $40 \mathrm{My}$, was initiated prior to regional sinistral strike-

1025 slip, continued through regional sinistral transcurrent movements and Acadian orogenesis and

1026 persisted, then for a further c. 7 My This broad spectrum of ages does not fit any existing model

1027 for regional-scale petrogenesis. It is difficult to envisage how slab break-off could generate large

1028 volumes of melt for over c. $37 \mathrm{My}$ in Connemara and not continue to feed other batholiths across

1029 Britain and Ireland after 400-390 Ma. Neither the model of Brown et al. (2008), nor that of

1030 possible subduction-driven magmatism (Rheic Ocean) proposed by McCarthy (2013), can

1031 account for the petrogenesis of the earlier constituents of the Galway Granite because

1032 transtension/subduction began at least $12 \mathrm{My}$ after the first pluton became emplaced.

1034 A consensus is now emerging: north of the Great Glen Fault, intrusions that are older than 430

1035 Ma can be attributed to subduction and thickening during the Scandian Orogeny (Dewey 1971;

1036 van Breemen \& Bluck 1981). For other granitoids north of the Orlock Bridge Fault, a slab break-

1037 off model of some type can account for the surge in plutonic activity at c. 420-400 Ma (Atherton

1038 \& Ghani 2002; Neilson et al. 2009). South of the Orlock Bridge Fault, intrusions have a different

1039 origin resulting in granitoids with ages $\leq 400 \mathrm{Ma}$ and S-types with I-type components. Whether

1040 Devonian transtension was the sole tectonic control or whether subduction and dehydration of

1041 the Rheic oceanic crust (McCarthy 2013) had a role in prolonging magmatism is unresolved. The

1042 composition of the Newry Complex is anomalous for its location and the petrogenetic story of

1043 the Galway batholith is still unclear. 
1045 Old Red Sandstone (Devonian) tectonics and sedimentation and the role of the Acadian 1046 orogeny

1048 Much debate over the last twenty-five years has centred around the extent and regional tectonic 1049 significance of Devonian deformation in Scotland (Norton et al. 1997), and how this might 1050 relate, if at all, to broadly coeval Acadian events south of the Iapetus Suture (Rogers et al. 1989;

1051 Dewey \& Strachan 2003; Mendum \& Noble 2010). Old Red Sandstone (Devonian) continental 1052 rocks of the Orcadian basin unconformably overlie deeply-eroded Moine and Dalradian 1053 metamorphic complexes around the Moray Firth, and on Orkney and Shetland (Trewin \& 1054 Thirlwall 2002, and references therein). In many parts of the mainland basin, the Old Red 1055 Sandstone rocks are undeformed, apart from local tilting, and there is more or less complete 1056 stratigraphic continuity from the Emsian to Fammenian. Local unconformities have been 1057 attributed to extensional faulting (Rogers et al. 1989) or an increase in extension-related 1058 subsidence. In contrast, Lower Old Red Sandstone deposits NW of the Moray Firth in Caithness 1059 were folded twice before deposition of unconformably overlying Middle Old Red Sandstone 1060 successions (Dewey \& Strachan 2003), and there is significant folding of the Middle Old Red 1061 Sandstone deposits of western Shetland (Mykura 1991; Seranne 1992).

1063 South of the Highland Boundary Fault, early Devonian strata of the Midland Valley are disposed 1064 in pre-late Devonian folds (e.g. Strathmore Syncline). These folds have been attributed to the 1065 Acadian orogenic event (Friend et al. 2000) that formed the slate belts of England and Wales 1066 during the late Emsian (Woodcock et al. 2007). Early Devonian strata just to the north and south 1067 of the Midland Valley are undeformed; therefore, it might be supposed that deformation of the

1068 Midland Valley succession resulted from localised sinistral reactivation of the Highland

1069 Boundary and Southern Upland faults during Acadian convergence. The same explanation could

1070 be invoked to explain the localized folding of Old Red Sandstone rocks north-west of the Moray

1071 Firth and in Shetland, both areas located close to the Great Glen-Walls Boundary fault system,

1072 although deformation in Shetland is significantly younger than any documented Acadian events 1073 in England and Wales. 
1075 An alternative view stems from recognition that folding need not necessarily signify crustal

1076 shortening; large-scale folding can occur during transtension (Dewey 2002). Krabbendam and

1077 Dewey (1998) demonstrated that widespread folding accompanied transtensional exhumation of

1078 coesite eclogites of the Western Gneiss Region in south-west Norway between c. 420 and 390

1079 Ma. Dewey and Strachan (2003) extended the concept across the wider North Atlantic region, 1080 proposing that sinistrally-transpressive Scandian collision was followed by a period of sinistral

1081 transtension that extended from the late Silurian into Middle Devonian times, creating the Old

1082 Red Sandstone basins and deforming their sedimentary fill. Critical to this model is the

1083 interpretation that many of the folds that deform the Old Red Sandstone successions in areas

1084 such as Shetland, Caithness and East Greenland are essentially syn-depositional (Seranne 1992).

1085 This interpretation separates the formation and deformation of the Scottish Old Red Sandstone

1086 successions from the broadly coeval Acadian orogeny that led to the formation of the slate belts

1087 of Wales and the Lake District (Woodcock et al. 2007,). This is reinforced by the realization that

1088 a substantial succession of now-eroded Old Red Sandstone rocks must have been deposited over 1089 northern England, most likely also in transtensional basins, prior to the Acadian orogeny (Soper

1090 \& Woodcock 2003). Regional transtension across northern England and southern Scotland was

1091 also invoked as a mechanism for generating the Trans-Suture Granites (see however, comments 1092 above).

1093

1094 Summary and models

1095

1096 Increasing knowledge of the Scottish Highlands, especially fine-scale geochronology linked

1097 convincingly to fabrics and structures, is leading to a deeper understanding of the complexity of

1098 their geological history between 1Ga and 400 Ma. Further advances will depend upon new very

1099 fine-scale mapping, geochronology, structural analysis, petrology, sedimentology, geochemistry,

1100 and high-resolution-heavy-mineral analysis. In developing tectonic models, one is faced with the

1101 pixel-size problem, that of linking small-scale complexity with large-scale simplicity (Dewey

1102 1975; Dewey \& Casey 2013). The whole of Scotland could fit within a very small portion of a

1103 plate boundary complex (Dewey 1982). Also, we are beset with the inversion problem; it is

1104 relatively easy to build numerical and kinematic forward models that make precise predictions

1105 about tectonic evolution but very difficult to impossible to build convincing tectonic models 
1106 from data, however much and in what detailed it is acquired. Also, an orogen can be "over1107 terraned" (Sengor \& Dewey 1990). The terrane concept (Coney et al. 1980) has been useful in 1108 the "outboard" parts of circum-Pacific accretionary orogens where terranes have been displaced, 1109 relative to adjacent terranes by, perhaps, thousands of kilometres but has led to an overzealous 1110 search for differences rather than similarities, and cryptic and hallucinosutures and transform 1111 boundaries in many orogens that show substantial along-strike continuity of zones. For example, 1112 we suggest, for strong geological reasons, that the Great Glen Fault must have at least $500 \mathrm{~km}$ of 1113 sinistral displacement. Conversely, the Highland Boundary Fault, because of its prominence and 1114 linearity, has been suggested to be a major sinistral transform roughly coincident with the 1115 principal Grampian major arc-continent suture; Tanner (2011) has argued, cogently, that the 1116 geology of the Highland Boundary Fault Zone does not permit this interpretation. Major 1117 'terraning' (terrane shuffling) is characteristic of orogens at continental margin, such as the 1118 Cordilleran system and collisional orogens where there is substantial strike-slip motion (Van 1119 Staal et al. 1998). Also, the term "terrane tectonics" is inappropriate (Sengor \& Dewey (1990); 1120 terraning is a product of processes inherent in plate kinematics, not another kind of tectonic 1121 process. Consequently, it is generally unwise to draw palaeo-tectonic sections across orogens

1122 because components of those sections may have been hundreds or thousands of kilometers from 1123 each other at the time for which the section is drawn.. However, in spite of all these potential 1124 pitfalls, we summarize what we perceive to be plausible models for the post-Grenville evolution 1125 of the Appalachian/Caledonian Laurentian margin as follows. From about 900 Ma to $600 \mathrm{Ma}$, 1126 slow intra-continental rifting in a multi-basin complex led to the deposition of the Moine 1127 assemblage and most of the Dalradian. The edge of the rifted zone in Scotland was probably the 1128 Grenville Front, later to become the Moine Thrust Zone. Within the Moine Supergroup, early 1129 rifting and magmatism was followed by Knoydartian shortening. The shortening seems to have 1130 no clear boundaries, no unconformities, and no molasse. The event may have been diffuse, far1131 field, intracontinental shortening (Dewey 2005) like the huge Carboniferous Peterman event of 1132 the Amadeus Basin in central Australia, the Antler event in Colorado, and the many examples of 1133 basin inversion, or it was part of a "Valhalla" continental margin accretionary event (Cawood et 1134 al. 2010). The latter interpretation, with Scotland and the Rockall Bank located between Baltica 1135 and Greenland at $1.0 \mathrm{Ga}$, is compatible with the interpretation of Loewy et al. (2011) that Coats 1136 Land, Antarctica, at the head of the Weddell Sea, was a small fragment of southern Laurentia 
1137 (present coordinates) and attached to the Kalahari craton of Africa at that time across a

1138 Grenvillian suture (Fig.3). This is also compatible with the so-called 'SAMBA' connection

1139 between the Sveconorwegian province of Baltica and the Sunsas orogen of Amazonia as

1140 proposed by Johansson (2014).

1142 From about 600 to 540 Ma, bimodal mafic (e.g. Lighhouse Cove Basalts, Tayvallich Volcanics)

1143 and silicic (e.g. Ben Vuirich and Carn Chuinneag granites) magmatism broke out along the

1144 Moine/Dalradian rifted belt. This was probably the result of accelerated rift-thinning of the

1145 Lithosphere, which led, in the latest Precambrian, to continental splitting and the origin of

1146 Iapetus and its rifted Laurentian margin from Alabama to northern Greenland. The edge of

1147 Iapetus probably coincided, roughly with the Baie Verte-Brompton-Clew Bay-Fair Head-

1148 Highland Boundary Fault Line, where two distinct ultramafic associations occur. First,

1149 serpentinized lherzolitic mélanges, pillow lavas, gabbro slices and dark grey phyllites (e.g. South

1150 Achill, Chew 2001, 2003; Henderson et al. 2009) are probably the result of early Cambrian

1151 extensional detachments bringing up sub-continental mantle at a magma-poor rifted margin ,with

1152 small partial melts, onto the sea floor. Second, the ophiolite suites (e.g. Shetland, Bute), are the

1153 remains of early Ordovician fore-arcs in the collision zone (Dewey \& Casey 2013). In the early

1154 Cambrian, subsidence of the NW Foreland shelf led to the establishment of the Eriboll to

1155 Durness continental shelf with notable, along-strike, detailed stratigraphical continuity along the

1156 length of the Appalachian-Caledonian Orogen.

1158 In the very broadest terms, the Grampian event (Fig. 3) that deformed the Dalradian and the

1159 Moine was the result of the short-lived collision of an oceanic arc(s) complex with the rifted

1160 Laurentian margin along the Baie Verte-Brompton-Clew Bay-Fair Head-Highland Boundary

1161 Fault Line (Van Staal et al. 1998). The contrast between the Highlands and Newfoundland is

1162 instructive. In Newfoundland, the fore-arc ophiolite was obducted onto the foreland to create a

1163 foreland basin upon which the Bay of Islands ophiolite complex is superbly preserved, and the

1164 Fleur-de-Lys is but a small remnant of the Moine/Dalradian. In contrast, in the Highlands, the

1165 Moine and Dalradian Supergroups occupy a huge volume and area, there is no Grampian

1166 foreland basin preserved, and ophiolites are preserved only in the suture zone and in Shetland as

1167 an ophiolite complex apparently banked against the Laurentian rifted margin. Perhaps the large 
1168 volume of rifted margin sediments prevented the extensive obduction of ophiolites across the

1169 Scottish margin and they were bull-dozed rather than deformed beneath an obducted ophiolite.

1170 Connemara is the only segment of the British and Irish Caledonides in which a convincing case

1171 can be made for the formation of north-verging Dalradian nappes beneath an obducting

1172 arc/ophiolite sheet.

1174 The Dalradian contains Laurentian faunas in the Leny Limestone and has Laurentian-derived

1175 clastic zircons. Furthermore, the arc that collided with the Laurentian margin contains Laurentian

1176 Ordovician faunas. These data prevent the Dalradian and its colliding arc from having an exotic

1177 origin; both must have been close to the Laurentian margin. Also, the arc complex had a huge

1178 strike length from Shetland at least to New York. It could not have moved through a narrow

1179 oceanic gap in the opposing Iapetan margin, as did the Caribbean arc move through a gap

1180 between North and South America.

1181

1182 The Scandian Orogeny affected only the Moine, in which it generated the latest phase of massive

1183 thrust slip in the Moine Thrust Zone and large-scale penetrative strain. How much of the

1184 imbricate and basement-involved thrusting in the Moine Thrust Zone is Scandian and/or

1185 Grampian is unclear and is a major problem that will be solved by direct dating of thrust

1186 surfaces. The Scandian Orogeny was generated by the mid-Silurian collision of Laurentia with

1187 Baltica. The absence of any evidence of the Scandian Orogeny over most of the Dalradian terrain

1188 suggests that the Dalradian was not in the jaws of the collisional vise, which, in turn, suggests

1189 that late Silurian/Devonian sinistral motion of at least $500 \mathrm{~km}$ along the Great Glen moved the

1190 Dalradian into its present position with respect to the Moine.

1192 Any single orogenic tectonic model, such as a westward-extruding wedge above the Moine

1193 Thrust and below the Banff Extensional Detachment, that purports to provide an explanation for

1194 the Grampian and Scandian as a single continuous, diachronous 45 my event, as in the

1195 Himalayas, cannot be viable. It is now clear that the short-lived Grampian event affected both the

1196 Moine and Dalradian, whereas the Scandian event is confined to the Moine (Fig 5); there was no

1197 simple westward-progression of deformation across the Highlands. Also, the Dalradian was not

1198 outboard of the Moine until after the Scandian collision. Similarly, orogenic lower crustal flow 
1199 models are inappropriate for the Grampian and Scandian Orogenies; the rocks are mostly 1200 metasediments with a coherent stratigraphy in greenschist to garnet-amphibolite facies of the 1201 middle and upper crust.

1203 We have merely scratched the surface of the myriad of problems that remain about our 1204 understanding of Caledonide geology, many of which depend upon a new generation of 1205 meticulous field mapping and outcrop observation. As Kevin Burke has remarked on many 1206 occasions, "little can be understood in geology without a detailed map". There are too few 1207 people with the skills and knowledge to design integrated research programmes that involve 1208 making maps and observations in the field where the truth resides. All modeling is important in 1209 giving us ideas and constraining kinematic models but it is facile solely to sit in front of a 1210 computer and compose drivel. There are now Professors of Geology who have never made a 1211 map, used a petrographic microscope, or studied rocks, minerals or fossils. We have composed 1212 this paper in an assertive style, and hope that it will inspire new generations of geologists to 1213 discover the joys and fulfillment of mapping and field observation and the analysis and synthesis 1214 of regional geology. There is much to be done.

\section{Acknowledgements}

1218 Many people, past and present, have, variously, helped, informed, encouraged, and inspired us.

1219 We recognize, especially Charles Lapworth, W. Q. Kennedy, Robert Shackleton, Bruce 1220 Chappell, Allan White, Celal Sengor, Peter Cawood, Tony Harris, Donny Hutton, Wally Pitcher, 1221 Paul Ryan, Jack Soper, David Chew, Graham Leslie, Maarten Krabbendam, Ed Stephens, and 1222 Cees Van Staal. William McCarthy's assistance with Figure 7 is acknowledged gratefully.

\section{Science editing by Maarten Krabbendam}

\section{References}

1227 Aftalion, M., van Breemen, 0. \& Bowes, D. 1984. Age constraints on basement of the Midland 1228 Valley of Scotland. Transaction of the Royal Society of Edinburgh: Earth Sciences, 1229 75, 53-64. 
1230 Alsop, G. I., Cheer, D. A., Strachan, R. A., Krabbendam, N., Kinny., P. D., Holdsworth, R. E. \& Leslie, A.G. 2010. Progressive fold and fabric evolution associated with regional strain gradients: a case study from across a Scandian ductile thrust nappe, Scottish Caledonides. In: Law, R., Butler, R. W. H., Holdsworth, R., Krabbendam, M. \& Strachan, R. A., (eds.) Continental tectonics and mountain building: the legacy of Peach and Horne. Geological Society, London, Special Publications, 335, 255-274.

Anderton, R. 1982. Dalradian deposition and the late Precambrian-Cambrian history of the N Atlantic region. a review of the early evolution of the Iapetus Ocean. Journal of the Geological Society of London, 139, 421-431.

Atherton, M. P. \& Ghani, A. A. 2002. Slab breakoff: a model for Caledonian, late granite syncollisional magmatism in the orthotectonic (metamorphic) zone of Scotland and Donegal, Ireland. Lithos, 62, 65-85.

Badenski, E., Daly, J. S. \& Whitehouse, M. J. 2011. Deep crustal metasedimentary xenoliths of the Scottish Midland Valley record Middle Devonian metamorphism of Wenlock sediments: p. 10 in $54^{\text {th }}$ Irish Geological Research Meeting, Galway, Ireland.

Barr, D., Roberts, A. M., Highton, A. J., Parsons, L. M. \& Harris, A.L. 1985. Structural setting and geochronological significance of the West Highland Granite Gneiss, a deformed early granite within the Proterozoic Moine rocks of NW Scotland. Journal of the Geological Society of London, 142, 663-675.

Brasier, M. D. \& Shields, G. 2000. Neoproterozoic chemostratigraphy and correlation of the Port Askaig glaciation, Dalradian Supergroup of Scotland. Journal of the Geological Society of London, 157, 909-914.

Bird, J.M. \& Dewey, J.F. 1970: Lithosphere plate-continental margin tectonics and the evolution of the Appalachian orogen. Geological Society of America Bulletin, 81, 103-136.

Bird, A. F., Thirlwall, M. F. \& Strachan, R. A. 2013, Lu-Hf and Sm-Nd dating of metamorphic garnet: evidence for multiple accretion events during the Caledonian orogeny in Scotland. Journal of the Geological Society of London, 170, 301-317.

Bonsor, H. C., Strachan, R. A., Prave, . R. \& Krabbendam, M. 2012, Sedimentology of the early Neoproterozoic Morar Group in northern Scotland: implications for basin models and tectonic setting. Journal of the Geological Society of London, 169, 53-65. 
1260 Bowes, D.R. 1968. The absolute time-scale and the subdivision of Precambrian rocks in Scotland. Geologiska Foreningens I Stockholm Forhandlingar, 90, 175-188.

1262 Brewer, M.S., Brook, M. \& Powell, D. 1979. Dating of the tectono-metamorphic history of the southwestern Moine, In: Harris, A.L., Holland, C.H. \& Leake, B.E. (eds) The Caledonides of the British Isles - Reviewed. Geological Society, London, Special Publications, 8, 129-137.

Bullard, E. C., Everett, J. E. \& Smith, A. G. 1965,=. The fit of the continents around the Atlantic. Philosophical Transactions of the Royal Society of London, 258a, 41-51.

1284 Bursnall, J. 1973. The Geology of Baie Verte. Ph. D thesis, University at Albany, State Universtity of New York. Journal of the Geological Society of London, 29, 335-414.

1288 Callaway, C. 1884, Notes on progressive metamorphism. Geological Magazine, 1, 218-224. 
1289 Cawood, P. A., Nemchin, A. A., Smith, M. \& Loewy, S. 2003. Source of the Dalradian Supergroup constrained by U-Pb dating of detrital zircon and implications for the East Laurentian margin. Journal of the Geological Society of London, 160, 231-246.

1292 Cawood, P.A., Nemchin, A.A., Strachan, R.A., Kinny, P.D. \& Loewy, S. 2004, Laurentian provenance and tectonic setting for the upper Moine Supergroup, Scotland, constrained by detrital zircons from the Loch Eil and Glen Urquhart successions. Journal of the Geological Society of London, 161, 863-874.

Cawood, P.A., Nemchin, A.A., Strachan, R.A., Prave, A.R. \& Krabbendam, M. 2007, Sedimentary basin and detrital zircon record along East Laurentia and Baltica during assembly and breakup of Rodinia. Journal of the Geological Society of London, 164, 257-275.

Cawood, P.A. \& Pisarevsky, S.A. 2006. Was Baltica right-way up or upside down in the Neoproterozoic? Journal of the Geological Society of London, 163, 753-759.

1301 Cawood, P.A., Strachan, R.A., Cutts, K.A., Kinny, P.D., Hand, M. \& Pisarevsky, S. 2010, Neoproterozoic orogeny along the margin of Rodinia: Valhalla orogen, North Atlantic. Geology, 38, 99-102.

1304 Cawood, P. A., Strachan R. A., Merle, R. E., Millar, I. L., Loewy, S. L.,Dalziel, I. W. D., Kinny, P. 1305 D., Jourdain, F., Nemchin, A. A. \& Connelly, J. N. (in press) Neoproterozoic to early Paleozoic history of East Laurentian margin. Bulletin of the Geological Society of America, in review.

1308 Chappell, B.W. 1996. Compositional variation within granite suites of the Lachlan Fold Belt: its 1309 causes and implications for the physical state of granite magma. Transactions of the Royal Society of Edinburgh: Earth Sciences, 87, 159-170.

1311 Chappell, B. W. \& White, A. J. R. 1974. Two contrasting granite types. Pacific Geology, 8, 173174.

1313 Chappell, B. W. \& White, A. J. R. 2001. Two contrasting granite types: 25 years later. Australian Journal of Earth Sciences, 48, 489-499.

1315 Chew, D. M. 2001. Basement protrusion origin of serpentinite in the Dalradian. Irish Journal of Earth Sciences, 19, 23-35. 
1317 Chew, D. M. 2003. Structural and stratigraphic relationships across the continuation of the Highland Boundary Fault in western Ireland. Geological Magazine, 140, 73-85.

1319 Chew, D. M., Daly, J. S., Page, L. M. \& Kennedy, M. J. 2003. Grampian orogenesis and the development of blueschist-facies metamorphism in western Ireland: Journal of the Geological Society of London, 160, 911-924.

Chew, D. M. \& Strachan, R. A. 2013. The Laurentian Caledonides of Scotland and Ireland. In: Scandinavia and related areas. Geological Society, London, Special Publications, 390, 45-91.

Coney, P.J., Jones, D.L. \& Monger, J.W.H. 1980. Cordilleran suspect terranes. Nature, London, 288, 329-333.

Coward, M. P. 1985. The thrust structures of southern Assynt, Moine thrust zone. Geological Magazine, 122, 596-607.

Cowie, J. W. 1974. The Cambrian of Spitzbergen and Scotland. In: Holland, C. H. (ed). Cambrian of the British Isles, Norden and Spitzbergen, Wiley, Chichester, 123-155.

Crowley, Q. 1997. Geology and geochemistry of the Galway Granite in the Inveran sector, Western Ireland: PhD Thesis, National University of Ireland, Galway.

1334 Cruden, A. R., Tobisch, O. T. \& Launeau, P. 1999. Magnetic fabric evidence for conduit-fed 1335 emplacement of a tabular intrusion: Dinkey Creek Pluton, central Sierra Nevada batholith, California. Journal of Geophysical Research, 104, 10511-10530.

Cutts, K. A., Kinny, P. D., Strachan, R., Hand, M., Kelsey, D. E., Emery, M., Friend, C. R. L. \& 1338 Leslie, A. G. 2010. Three metamorphic events recorded in a single garnet: Integrated phase modelling, in situ LA-ICPMS and SIMS geochronology from the Moine Supergroup, NW Scotland. Journal of Metamorphic Geology, 28, 249-267.

Dalziel, I. W. D. 1966. A structural study of the granitic gneiss of western Ardgour, Argyll and Inverness-shire. Scottish Journal of Geology, 2, 125-152.

Dalziel, I.W.D. 2010. The North-West Highlands Memoir: A century-old legacy for understanding Earth before Pangaea. In: Continental Tectonics and Mountain Building, Butler, R., Holdsworth, R., Krabbendam, M., Law, R. \& Strachan, R., (Eds). Geological Society, London, Special Publications, 335, 187-204. 
1347 Dalziel, I. W. D. and Johnson, M. R. W. 1963,Evidence for the geological dating of the granitic gneiss of western Ardgour. Geological Magazine, 100, 244-254.

Dalziel, I. W. D. \& Soper, N. J. 2001. Neoproterozoic extension on the Scottish Promontory of Laurentia: paleogeographic and tectonic implications. Journal of Geology, 109, 299317.

Daly, J. S., Aitcheson, S. J., Cliff, R. A., Gayer, R. A. \& Rice, A. H. N. 1991. Geochronological evidence from discordant plutons for a late Proterozoic orogen in the Caledonides of Finnmark, northern Norway. Journal of the Geological Society of London, 148, 2940.

Daly, J. S. \& Flowerdew, M. J. 2005. Grampian and late Grenville events recorded by mineral geochronology near a basement-cover contact in north Mayo, Ireland. Journal of the Geological Society, 162, 163-174.

Davidson, D., M. 1980. Precambrian Geology of the Van Horn area, Texas. New Mexico Geological Society Guidebook, 31 ${ }^{\text {st }}$ Field Conference, Trans-Pecos Region, 151-153.

Dewey, J.F. 1963, The lower Palaeozoic stratigraphy of central Murrisk, Co. Mayo, Eire, and the evolution of the South Mayo Trough. Quarterly Journal of the Geological Society of London, 119, 313-344.

Dewey, J.F. 1969. Evolution of the Appalachian-Caledonian Orogen. Nature, London, 222, 124129.

Dewey, J.F. . 1971. A model for the Lower Palaeozoic evolution of the southern margin of the early Caledonides of Scotland and Ireland. Scottish Journal of Geology, 7, 219-240.

Dewey, J.F. 1975. Finite plate evolution: some implications for the evolution of rock masses at plate margins. American Journal of Science, 275-A, 260-284.

1373 Dewey, J. F. 2005. Orogeny can be very short. Proceedings of the National Academy of Sciences of the United States of America, 102, 15286-15293.

1375 Dewey, J. \& Casey, J. 2011. The origin of obducted large-slab ophiolite complexes, In: Brown, D. \& Ryan, P.D (eds), Arc-Continent Collision. Springer Berlin Heidelberg, pp. 431444. 
1378 Dewey, J.F. \& Casey, J.F. 2013. The sole of an ophiolite: the Ordovician Bay of Islands Complex, Newfoundland. Journal of the Geological Society of London, 170, 715-722.

Dewey, J. F. \& Mange, M. A. 1999, Petrography of Ordovician and Silurian sediments in the western Irish Caledonides: tracers of a short-lived Ordovician continent-arc collision orogeny and the evolution of theLaurentian Appalachian-Caledonian margin. In: MacNoicaill, C. \& Ryan, P.D. Continental Tectonics. Geological Society, London, Special Publications, 164, 55-107.

Dewey, J.F. \& Shackleton, R.M. 1984. A model for the evolution of the Grampian tract in the early Caledonides and Appalachians Nature, London, 312, 115-120.

Dewey, J.F. \& Strachan, R.A. 2003. Changing Silurian-Devonian relative plate motion in the Caledonides: sinistral transpression to sinistral transtension. Journal of the Geological Society of London, 160, 219-229.

Draut, A. E. \& Clift, P. D. 2001. Geochemical evolution of arc magmatism during arc-continent collision, South Mayo, Ireland. Geology, 29, 543-546.

Elliott, D. \& Johnson, M.R.W. 1980. Structural evolution in the northern part of the Moine thrust belt, NW Scotland. Transactions of the Royal Society of Edinburgh: Earth Sciences, 71, 69-96.

Feely, M., Leake, B. E., Baxter, S., Hunt, J. \& Mohr, P. 2006. A Geological Guide to the Granite of the Galway Batholith, Connemara, western Ireland. Geological Survey of Ireland, 62p.

Feely, M., Selby, D., Conliffe, J. \& Judge, M. 2007. Re-Os geochronology and fluid inclusion microthermometry of molybdenite mineralisation in the late-Caledonian Omey Granite, western Ireland. Applied Earth Science, 116, 143-149.

1401 Feely, M., Selby, D., Hunt, J. \& Conliffe, J. 2010. Long-lived granite-related molybdenite 1402 mineralization at Connemara, western Irish Caledonides. Geological Magazine, 147, 886-894.

1404 Fletcher, T.P. \& Rushton, W. A. 2007. The Cambrian fauna of the Leny Limestone, Perthshire, 1405 Scotland. Earth and Environmental Science Transactions of the Royal Society of Edinburgh, 98, 199-218 
Flinn, D. 1958. The nappe structure of north-east Shetland. Quarterly Journal of the Geological Society of London, 114, 107-136.

Fowler, M. B., Henney, P. J., Darbyshire, D. P. F. \& Greenwood, P. B. 2001. Petrogenesis of high Ba-Sr granites: the Rogart pluton, Sutherland. Journal of the Geological Society of London, 158, 521-534.

1413

Fowler, M. B., Kocks, H., Darbyshire, D. P. F. \& Greenwood, P. B. 2008. Petrogenesis of high BaSr plutons from the Northern Highlands Terrane of the British Caledonian Province. Lithos, 105, 129-148.

Friend, C.R.L., Jones, K.A. \& Burns, I.M. 2000, New high-pressure granulite facies event in the Moine Supergroup, northern Scotland: implications for Taconic (early Caledonian) crustal evolution. Geology, 28, 543-546.

Friend, C. R. L. \& Kinny, P. D. 2001. A reappraisal of the Lewisian Gneiss Complex: geochronological evidence for its tectonic assembly from disparate terranes in the Proterozoic. Contributions to Mineralogy and Petrology, 142, 198-218.

Friend, C.R.L., Strachan, R.A. \& Kinny, P.D. 2008. U-Pb zircon dating of basement inliers within the Moine Supergroup, Scottish Caledonides: implications of Archaean protolith ages. Journal of the Geological Society of London, 165, 807-815.

Friend, C.R., Strachan, R.A., Kinny, P.D. \& Watt, G.R. 2003. Provenance of the Moine Supergroup of NW Scotland: evidence from geochronology of detrital and inherited zircons from sediments, granites and migmatites. Journal of the Geological Society of London, 160, 247-257.

Friend, C.R.L., Kinny, P.D., Rogers, G., Strachan, R.A. \& Paterson, B.A. 1997. U—Pb zircon geochronological evidence for Neoproterozoic events in the Glenfinnan Group (Moine Supergroup): the formation of the Ardgour granite gneiss, north-west Scotland. Contributions to Mineralogy and Petrology, 128, 101-113.

Geikie, A. 1884. The crystalline rocks of the Scottish Highlands. Nature, London, 31, 29-31. Geikie, A. 1893. On the pre-Cambrian rocks of the British Isles. Journal of Geology, 1, 1-14. 
1435 Giletti, B.J., Moorbath, S. \& Lambert, R.St.J. 1961. A geochronological study of the metamorphic complexes of the Scottish Highlands. Quarterly Journal of the Geological Society of London, 117, 233-272.

Goodenough, K. M., Millar, I., Strachan, R. A., Krabbendam, M. \& Evans, J. A. 2011. Timing of regional deformation and development of the Moine Thrust Zone in the Scottish Caledonides: constraints from the U-Pb geochronology of alkaline intrusions. Journal of the Geological Society of London, 168, 99-113.

Goodenough, K. M., Crowley, Q. G., Krabbendam, M. \& Parry, S. F. 2013. New U-Pb age constraints for the Laxford Shear Zone, NW Scotland: Evidence for tectonomagmatic processes associated with the formation of a Paleoproterozoic supercontinent. Precambrian Research, 233, 1-19.

Gray, J. R. \& Yardley, B. W. D. 1979. A Caledonian blueschist from the Irish Dalradian. Nature, London, 278, 736-737.

Grogan, S. E. \& Reavy, R. J. 2002. Disequilibrium textures in the Leinster Granite Complex, SE Ireland: evidence for acid-acid magma mixing. Mineralogical Magazine, 66, 929939.

Hall, J., Brewer, J.A., Matthews, D.H. \& Warner, M. 1984. Crustal structure across the Caledonides from the WINCH seismic reflection profile: Influences on the evolution of the Midland Valley of Scotland. Transactions of the Royal Society of Edinburgh: Earth Sciences, 75, 97-109.

Halliday, A. N., Graham, C. M., Aftalion, M. \& Dymoke, P. 1989. The depositional age of the Dalradian Supergroup: U-Pb and Sm-Nd isotopic studies of the Tayvallich Volcanics, Scotland. Journal of the Geological Society of London, 146, 3-6.

Harmon, R. S. \& Halliday, A. N. 1980. Oxygen and Strontium isotope relationships in the British late Caledonian Granites. Nature, London, 283, 21-25.

Harris, A. L., Haselock, P. J., Kennedy, M. J. \& Mendum, J. R. 1994. The Dalradian Supergroup in Scotland, Shetland and Ireland. In: Gibbons, W. \& Harris, A. L. (eds). A revised correlation of Precambrian rocks in the British Isles. Geological Society, London, Special Report, 22, 3-53. 
1464 Henderson, W. G. \& Robertson, A. H. F. 1982. The Highland Border rocks and their relation to

1465

1466

1467

1468

1469

1470

1471

1472

1473

1474

1475

1476

1477

1478

1479

1480

1481

1482

1483

1484

1485

1486

1487

1488

1489

1490

1491

1492 marginal basin development in the Scottish Caledonides. Journal of the Geological Society of London, 139, 433-450.

Henderson, W. G., Tanner, P. W. G. \& Strachan, R. A. 2009. The Highland Border Ophiolite of Scotland: observations from the Highland Workshop field excursion of April 2008. Scottish Journal of Geology, 45, 13-18.

Holdsworth, R.E., Harris, A.L. \& Roberts, A.M. 1987. The stratigraphy, structure and regional significance of the Moine rocks of Mull, Argyllshire, W Scotland. Geological Journal, 22, 83-107.

Holdsworth, R.E., Strachan, R.A. \& Harris, A.L. 1994, Precambrian rocks in northern Scotland east of the Moine Thrust: the Moine Supergroup. In: Gibbons, W. \& Harris, A.L., (eds) A revised correlation of Precambrian rocks in the British Isles. Geological Society, London, Special Report, 22, 23-32.

Hutton, D.H.W. 1982. A tectonic model for the emplacement of the Main Donegal Granite, NW Ireland. Journal of the Geological Society of London, 139, 615-631.

Hutton, D.H.W. \& Reavy, R.J. 1992, Strike-slip tectonics and granite petrogenesis. Tectonics, 11, 960-967.

Hutton, J. 1788, Theory of the Earth. Transactions of the Royal Society of Edinburgh, 1, 209-304

Ishihara, S. 1977.The magnetite-series and ilmenite series granitic rocks. Mining Geology, 27, 293305.

Johannson, A. 2014, From Rodinia to Gondwana with the SAMBA” model-A distant view from Baltica towards Amazonia and beyond. Precambrian Research, 244, 226-235.

Johnson, M. R. W., Kelley, S. P., Oliver, G. J. H. \& Winter, D. A. 1985. Thermal effects and timing of thrusting in the Moine Thrust zone. Journal of the Geological Society of London, 142, 863-874.

Johnstone, G.S. 1975. The Moine Succession. In: Harris, A.L., Shackleton, R.M., Watson, R.M., Watson, J.V., Downie, C., Harland, W.B. \& Moorbath, S. (eds) A Correlation of Precambrian rocks in the British Isles. Geological Society, London, Special Report, 6, 30-42. 
1493 1494

1495

1496

1498

1499

1500

1501

1502

1503

1504

1505

1506

1507

1508

1509

1510

1511

1512

1513

1514

1515

1516

1517

1518

1519

1520

1521

1522

Johnstone, G.S., Smith, D.I. \& Harris, A.L. 1969. The Moinian Assemblage of Scotland. In: Kay, M. (ed.) North Atlantic geology and continental drift. American Association of Petroleum Geologists, Memoirs, 12, 159-180.

Kelling, G. 1961, The Stratigraphy and Structure of the Ordovician rocks of the Rhinns of Galloway. Quarterly Journal of the Geological Society of London, 117, 37-75

Kennedy, M. J. 1980. Serpentinite-bearing melange in the Dalradian of County Mayo and its significance in the development of the Dalradian basin. Journal of Earth Sciences of the Royal Dublin Society, 3, 117-126.

Kennedy, M. J. \& Menuge, J. F. 1992, The Iniskea Division of northwest Mayo: Dalradian cover rather than pre-Caledonian basement. Journal of the Geological Society of London, 149, $167-170$.

Kennedy, W. Q. ,1946, The Great Glen Fault. Quarterly Journal of the Geological Society of London, 102, 41-76.

Kennedy, W. Q. 1955, The tectonics of the Morar anticline and the problems of the north-west Caledonian front. Quarterly Journal of the Geological Society of London, 110, 375390.

Kennedy, W. Q. 1964. The structural deformation of Africa in the Pan-African ( \pm 500 m.y.) tectonic episode. Leeds University Research Institute of African Geology, Annual Report, 8, 48-49.

Kennedy, W. Q., Lawrie, T. R,, \& Simpson, J. B. 1943. Commercial mica in Scotland, Part 2, Preliminary Description of some occurrences North of the Great Glen. Geological Survey of Great Britain Wartime Pamphlets, Department of Scientific and Industrial Research, 34, 9p.

Kinny, P.D., Friend, C. R. L., Strachan, R. A., Watt, G. R. \& Burns, I. M. 1999.,U—Pb geochronology of regional migmatites, East Sutherland, Scotland: evidence for crustal melting during the Caledonian orogeny. Journal of the Geological Society of London, 156, 1143-1152.

Kinny, P. D., Strachan, R. A., Rogers, G. R., Friend, C. R. L. \& Kocks, H. 2003a, U—Pb geochronology of deformed meta-granites in central Sutherland, Scotland: evidence for widespread Silurian metamorphism and ductile deformation of the Moine 
1523

1524

1525

1526

1527

1528

1529

1530

1531

1532

1533

1534

1535

1536

1537

1538

1539

1540

1541

1542

1543

1544

1545

1546

1547

1548

1549

1550

1551

1552

1553

Supergroup during the Caledonian orogeny. Journal of the Geological Society of London, 160, 259-269.

Kinny, P. D., Strachan, R. A., Kocks, H., Friend, C. R. L. 2003b, U-Pb geochronology of late Neoproterozoic augen granites in the Moine Supergroup, NW Scotland: dating of riftrelated, felsic magmatism during supercontinent break-up? Journal of the Geological Society of London, 160, 925-934.

Kirkland, C.L., Strachan, R.A. \& Prave, A.R. 2008, Detrital zircon signature of the Moine Supergroup, Scotland: Contrasts and comparisons with other Neoproterozoic successions within the circum-North Atlantic region. Precambrian Research, 163, 332-350.

Krabbendam, M., Leslie, A. G. \& Goodman, S. 1997. Generation of the Tay Nappe, Scotland, by large-scale SE-directed shearing. Journal of the Geological Society of London, 154, $15-24$.

Krabbendam, M. \& Dewey, J.F. 1998, Exhumation of UHP rocks by transtension in the Western Gneiss Region, Scandinavian Caledonides. Geological Society, London, Special Publication., 135, 159-181.

Krabbendam, M., Prave, A.R. \& Cheer, D. 2008, A fluvial origin for the Neoproterozoic Morar Group, NW Scotland: implications for Torridon-Morar group correlation and the Grenville Orogen Foreland Basin. Journal of the Geological Society of London, 165, 379-394.

Lambert, R. St.J. 1969. Isotopic studies relating to the Pre-Cambrian history of the Moinian of Scotland. Proceedings of the Geological Society of London, 1652, 243-245.

Lambert, R. St.J. \& Long, L. E. 1963, Rb—Sr isotopic ages from the Moine series. In: Johnson, M.R.W. \& Stewart, F.H. (eds) The British Caledonides. Oliver \& Boyd, Edinburgh, 217-246.

Lapworth, C. 1883, On the structure and metamorphism of the rocks of the Durness-Eriboll district. Proceedings of the Geological Association, 8, 438-442.

Lapworth, C. 1885, The Highland Controversy in British geology: its causes, course and consequence. Nature, London, 32, 558-559.

Leake, B. E. 2006. Mechanism of emplacement and crystallisation history of the northern margin and centre of the Galway Granite, western Ireland. Transactions of the Royal Society 
of Edinburgh: Earth Sciences, 97, 1-23.

1555

1556

1557

1558

1559

1560

1561

1562

1563

1564

1565

1566

1567

1568

1569

1570

1571

1572

1573

1574

1575

1576

1577

1578

1579

1580

1581

1582

1583

Leggett, J. K., McKerrow, W. S. \& Eales, M. H. 1979. The Southern Uplands of Scotland; a Lower Paleozoic accretionary prism. Journal of the Geological Society of London, 136, 755770.

Leslie, A. G, Smith, M. \& Soper, N.J. 2008, Laurentian margin evolution and the Caledonian orogeny-A template for Scotland and East Greenland. Geological Society of America Memoirs, 202, 307-343.

Li, Z.X., Bogdanova, S.V., Collins, A.S., Davidson, A., De Waele, B., Ernst, R.E., Fitzsimons, I.C.W., Fuck, R.A., Gladkochub, D.P., Jacobs, J., Karlstom, K.E., Lu, S., Natapov, L.M., Pease, V., Pisarevsky, S.A., Thrane, K. \&Vernikovsky, V. 2008, Assembly, configuration, and break-up history of Rodinia: A synthesis. Precambrian Research, 160, $179-210$.

Loewy, S., Dalziel, I. W. D., Pisarevsky, s., Connelly, J. N., Tait, J., Hanson, R. E. \& Bullen, D. S. 2011.Coats Land crustal block, East Antarctica: A tectonic tracer for Laurentia? Geology, 39, 859-862.

Lorenz, H., Gee, D. G., Larionov, A. N. \& Majka, J. 2012. The Grenville-Sveconorwegian orogen in the high Arctic. Geological Magazine, 149, 875-891.

MacCulloch, J.,1836, Memoirs to H. M. Treasury respecting a geological survey of Scotland, London, 21 pp.

MacCulloch, J. 1840, A geological map of Scotland by Dr. MacCulloch: G. F. Cruchley, London. MacDonald, R. \& Fettes, D. J.,2007, The tectonomagmatic evolution of Scotland. Transactions of the Royal Society of Edinburgh: Earth Sciences, 97, 213-295.

Manatschal, G. \& Muntener, O. 2009, A type sequence across an ancient magma-poor ocaencontinent transition: the example of the western Alpine Tethys ophiolites. Tectonophysics, 473, 4-19.

Mange, M. A., Dewey, J. F. \& Floyd, J. 2005, The origin, evolution and provenance of the Northern Belt (Ordovician) of the Southern Uplands Terrane, Scotland: a heavy mineral perspective. Proceedings of the Geologists' Association, 116, 251-280.

McAteer, C. A., Daly, J. S., Flowerdew, M. J., Whitehous, M. J. \& Kirkland, C. L. 2010a, A Laurentian provenance for the Dalradian rocks of north Mayo, Ireland, and evidence 
1584

1585

1586

1587

1588

1589

1590

1591

1592

1593

1594

1595

1596

1597

1598

1599

1600

1601

1602

1603

1604

1605

1606

1607

1608

1609

1610

1611

1612

1613

for an original basement-cover contact with the underlying Annagh Gneiss Complex. Journal of the Geological Society of London,, 167, 1033-1048.

McAteer, C., Daly, J., Flowerdew, M. \& Whitehouse, M. 2010b. Dalradian Grampian Group affinity for the Bowmore Sandstone Group, Islay, SW Scotland. Scottish Journal of Geology, 46, 97-111.

McAteer, C. A., Daly, J. S., Flowerdew, M. J., Connelly, J. N., Housh, T. B. \& Whitehouse, M. J. 2010c, Detrital zircon, detrital titanite and igneous clast U-Pb geochronology and basement-cover relationships of the Colonsay Group, SW Scotland: Laurentian provenance and correlation with the Neoproterozoic Dalradian Supergroup. Precambrian Research, 181, 21-42.

McCarthy, W. J. 2013, An evaluation of orogenic kinematic evolution utilizing crystalline and magnetic anisotropy in granitoids. Ph.D thesis, National University of Ireland, Cork.

McKerrow, W. S., MacNiocaill, C. \& Dewey, J. F. 2000, The Caledonian Orogeny redefined. Journal of the Geological Society of London, 157, 1149-1154.

Meighan, I. G., Hamilton, M. A., Gamble, J. A., Ellam, R. N. \& Cooper, M. R. 2003. The Caledonian Newry Complex, NE Ireland: new U-Pb ages, a subsurface extension and magmatic epidote. Joint meeting, Geological Society of America, Northeastern Section, Atlantic Geoscience Society, 79.

Mendum, J.R. \& Noble, S.R. 2010, Mid-Devonian sinistral transpressional movements on the Great Glen Fault: the rise of the Rosemarkie Inlier and the Acadian event in Scotland. In: Law, R., Butler, R. W. H., Holdsworth, R. ., Krabbendam, M. \& Strachan, R. A., (eds.) Continental tectonics and mountain building: the legacy of Peach and Horne. Geological Society, London, Special Publications, 335, 161-187.

Millar, I. L. 1999,Neoproterozoic extensional basic magmatism associated with emplacement of the West Highland granite gneiss in the Moine Supergroup of NW Scotland. Journal of the Geological Society of London, 156, 1153-1162.

Molyneux, S.,G. 1998, An upper Dalradian microfossil reassessed. Journal of the Geological Society of London, 155, 740-743.

Muir, R. J., Fitches, W. R., Maltman, A. J. \& Bentley, M. R., 1994, Precambrian rocks of the southern Inner Hebrides-Malin Sea region: Colonsay, west Islay, Inishtrahull and 
1614

1615

1616

1617

1618

1619

1620

1621

1622

1623

1624

1625

1626

1627

1628

1629

1630

1631

1632

1633

1634

1635

1636

1637

1638

1639

1640

1641

1642

1643

1644
Iona. In: Gibbons, W. \& Harris, A.L., (eds) A revised correlation of Precambrian rocks in the British Isles. Geological Society, London, Special Report, 22, 54-58.

Murchison, R. I 1859. On the succession of the older rocks of the northernmost counties of Scotland with some observations on the Orkney and Shetland islands. Quarterly Journal of the Geological Society of London,, 15, 353-421

Murchison, R. I. \& Geikie, A. 1861. On the altered rocks of the western islands of Scotland, and the north-western and central Highlands. Quarterly Journal of the Geological Society of London, 17, 171-229.

Mykura, W. 1991. Old Red Sandstone. In: Craig, G.Y. (ed.) Geology of Scotland. Geological Society, London, 297-344.

Neilson. J. C., Kokelaar, B. P. \& Crowley, Q. G. 2009. Timing, relations, and cause of plutonic and volcanic activity of the Siluro-Devonian post-colisional magmatic episode in the Grampian Terrane Scotland. Journal of the Geological Society of London, 166, 545561.2009

Nelson, K. \& Casey, J.F. 1979. Ophiolite detritus in the Upper Ordovician flysch of Notre Dame Bay and its bearing on the tectonic evolution of western Newfoundland. Geology, 7, 27-31.

Nicol, J. 1861. On the structure of the Northwestern Highlands and the Relations of the Gneiss, Red Sandstone, and Quartzite of Sutherland. Quarterly Journal of the Geological Society of London, 17, 85.

Norton, M. G., McClay, K. R. \& Way, N.A., 1997. Tectonic evolution of Devonian basins in northern Scotland and southern Norway. Norsk Geologisk Tidsskrit, 67, 323-338.

O’Connor, P. J., Aftalion, M. \& Kennan, P. S. 1989. Isotopic U-Pb ages from the Leinster Granite, southeast Ireland. Geological Magazine, 126, 725-728.

Oldroyd, D. 1990. The Highland Controversy: Constructing geological knowledge through fieldwork in Nineteenth Century Britain. Chicago University Press, Chicago, 438p.

Oliver, G. J. H., Wilde, S. A. \& Wan, Y. 2008. Geochronology and dynamics of Scottish granitoids from the late Neoproterozoic break-up of Rodinia to Palaeozoic collision. Journal of the Geological Society of London, 165, 661-674.

Park, R.G. 1992. Early Proterozoic tectonic overview of the northern British Isles and neighbouring terrains in Laurentia and Baltica. Precambrian Research, 68, 65-79. 
1645 Park, R. G. 1994. Early Proterozoic tectonic overview of the northern British Isles and neighbouring terrains in Laurentia and Baltica. Precambrian Research, 68, 65-79.

1647 Park, R. G., Stewart, A. D. \& Wright, D. T. 2002. The Hebridean terrane. In: Trewin, N. H. (ed). The Geology of Scotland, The Geological Society, London, 45-80.

1649

1650

1651

1652

1653

1654

1655

1656

1657

1658

1659

1660

1661

1662

1663

1664

1665

1666

1667

1668

1669

1670

1671

1672

1673

1674
Parsons, I. 1979. The Assynt alkaline suite. In: Harris, A. L., Holland, C. H. \& Leake, B. E. (eds). The Caledonides of the British Isles - reviewed. Geological Society, London, Special Publication, 8, 667-681.

Peach, B. N., Horne, J., Gunn, W., Clough, C. T., Hinxman, L. W. \& Teall, J. J. H. 1907. The Geological Structure of the Northwest Highlands of Scotland. Memoirs of the Geological Survey of Great Britain, 688 p.

Peach, B. N. \& Horne, J. 1884, Report on the Geology of North-west of Sutherland. Nature, London, 21, 31.

Peters, D. 2001. A geochemical and geochronological assessment of the Great Glen Fault as a terrane boundary. Ph. D. Thesis, University of Keele.

Piasecki, M. A. J. \& van Breemen, O. 1983, Field and isotopic evidence for a c. 750 Ma tectonothermal event in the Moine rocks of the central Highland region of the Scottish Caledonides. Transactions of the Royal Society of Edinburgh: Earth Sciences, 73, 119-134.

Pitcher, W. S. 1982. Granite type and tectonic environment. In: Hsu, K.J. (ed.) Mountain Building Processes. Academic Press, London, 19-40.

Pitcher, W. S. \& Berger, A. R. 1972, The Geology of Donegal: A Study of Granite Emplacement and Unroofing. Wiley-Interscience, New York and London, 435 p.

Playfair, J. 1802, Illustrations of the Huttonian Theory of the Earth. Cadell and Davies, London. Poole, A. B. \& Spring, J. S. 1974, Major structures in Morar and Knoydart, NW Scotland, Journal of the Geological Society of London, 130, 43-53.

Powell, D. 1974, Stratigraphy and structure of the western Moine and the problem of Moine orogenesis. Journal of the Geological Society of London, 130, 575-593.

Raine, R. \& Smith, M. 2012. Sequence stratigraphy of the Scottish Laurentian Margin and recognition of the Sauk Megasequence. In: Derby, J., Fritz, R., Longacre, S., Morgan, W. \& Sternbach, C. (eds). The Great American Carbonate Bank: The Geology and 
1675

1676

1677

1678

1679

1680

1681

1682

1683

1684

1685

1686

1687

1688

1689

1690

1691

1692

1693

1694

1695

1696

1697

1698

1699

1700

1701

1702

1703

1704

Economic Resources of the Cambrian-Ordovician Sauk Megasequence of Laurentia AAPG Memoir, 575-596.

Ramsay, J. G. 1957. Superimposed folding at Loch Monar, Inverness-shire and Ross-shire. Quarternary Journal of the Geological Society of London, 113, 271-308.

Ramsay, J. G. 1960. The deformation of earlier linear structures in areas of repeated folding. Journal of Geology, 68, 75-93.

Ramsay, J. G. 1962. Interference patterns produced by the superposition of folds of similar type. Journal of Geology, 70, 466-481.

Ramsay, J., G. 1963, Structure and metamorphism of the Moine and Lewisian rocks of the northwest Caledonides. In: Johnson, M. R. W. \& Stewart, F. H., (Eds), The British Caledonides. Oliver and Boyd, Edinburgh and London, p.143-175.

Ramsay, J. G. \& Spring, J. S. 1962, Moine stratigraphy in the Western Highlands of Scotland. Proceedings of the Geologists’ Association, 73, 295-322.

Read, H. H. 1961, Aspects of the Caledonian magmatism in Britain: Liverpool and Manchester Geological Journal, 2, 653-683.

Roberts, A.M. \& Harris, A.L. 1983. The Loch Quoich Line - a limit of early Palaeozoic crustal reworking in the Moine of the northern Highlands of Scotland. Journal of the Geological Society of London, 140, 883-892.

Roberts, A.M., Strachan, R.A., Harris, A.L., Barr, D. \& Holdsworth, R.E. 1987. The Sgurr Beag nappe: a reassessment of the northern Highland Moine, Bulletin of the Geological Society of America, 98, 497-506.

Rock, N. M. S., Gaskarth, J. W., Rundle, C. C. 1986. Late Caledonian Dyke-Swarms in Southern Scotland: A Regional Zone of Primitive K-Rich Lamprophyres and Associated Vents. Journal of Geology, 94, 505-522.

Rogers, G., Dempster, T.J., Bluck, B.J. \& Tanner, P.W.G. 1989. A high-precision age for the Ben Vuirich granite: implications for the evolution of the Scottish Dalradian Supergroup. Journal of the Geological Society of London, 146, 789-798.

Rogers, G. \& Dunning, G. R. 1991, Geochronology of appinitic and related granitic magmatism in the W Highlands of Scotland: constraints on the timing of transcurrent fault movement. Journal of the Geological Society of London, 148, 17-27. 
1705 Rogers, G., Kinny, P.D., Strachan, R.A., Friend, C.R.L. \& Paterson, B.A. 2001. U—Pb

1706

1707

1708

1709

1710

1711

1712

1713

1714

1715

1716

1717

1718

1719

1720

1721

1722

1723

1724

1725

1726

1727

1728

1729

1730

1731

1732

1733 geochronology of the Fort Augustus granite gneiss: constraints on the timing of Neoproterozoic and Palaeozoic tectonothermal events in the NW Highlands of Scotland. Journal of the Geological Society of London, 158, 7-14.

Rogers, G., Hyslop, E. K., Strachan, R. A., Paterson, B. A. \& Holdsworth, R. E. 1998. The structural setting and $\mathrm{U}-\mathrm{Pb}$ geochronology of Knoydartian pegmatites in $\mathrm{W}$. Inverness-shire: evidence for Neoproterozoic tectonothermal events in the Moine of NW Scotland. Journal of the Geological Society of London, 155, 685-696.

Ryan, P. D. \& Dewey, J. F. 2004, The South Connemara Group reinterpreted: a subductionaccretion complex in the Caledonides of Galway Bay. Journal of Geodynamics, 37, 513-529.

Ryan, P. D., Soper, N. J., Snyder, D. B., England, R. W. \& Hutton, D. H. W. 1995, The AntrimGalway Line: a resolution of the Highland Border Fault enigma of the Caledonides of Britain and Ireland. Geological Magazine, 132, 171-84.

Sanders, I.S., Van Calsteren, P.W.C. \& Hawkesworth, C.J. 1984. A Grenville Sm—Nd age for the Glenelg eclogite in northwest Scotland. Nature, London, 312, 439-440.

Searle, M., Law, R., Dewey, J. F. \& Streule, M. 2010. Structure and tectonic position of the Borolan-Ledmore alkaline suite in the Assynt Culmination. In: Law, R., Butler, R. W. H., Holdsworth, R. E., Krabbendam, M. \& Strachan, R. A. (eds). Continental Tectonics and Mountain Building: The Legacy of Peach and Horne. Geological Society, London, Special Publication, 335, 383-404

Selby, D., Creaser, R. A. \& Feely, M. 2004, Accurate and precise Re-Os molybdenite dates from the Galway Granite, Ireland: Critical comment on "Disturbance of the Re-Os chronometer of molybdenites from the late-Caledonian Galway Granite, Ireland, by hydrothermal fluid circulation". Geochemical Journal, 35, 29-35.

Séranne, M. 1992. Devonian extensional tectonics versus Carboniferous inversion in the northern Orcadian basin, Scotland. Journal of the Geological Society of London, 149, 27-37. Sengör, A.M.C. \& Dewey, J.F. 1990. Terranology: vice or virtue? Philosophical Transactions of the Royal Society of London, 313, 457-477. 
1734 Seranne, M. 1992, Devonian extensional tectonics versus Carboniferous inversion in the northern

1735

1736

1737

1738

1739

1740

1741

1742

1743

1744

1745

1746

1747

1748

1749

1750

1751

1752

1753

1754

1755

1756

1757

1758

1759

1760

1761

1762

Orcadian basin. Journal of the Geological Society of London, 149, 27-37.

Shackleton, R. M. 1958, Downward-facing structures of the Highland Border. Quarterly Journal of the Geological Society of London, 113, 361-393

Sherlock, S. C., Kelley, S. P., Zalasiewicz, J. A., Schofield, D. I., Evans, J. A., Merriman, R. J. \& Kemp, S. J. 2003. Precise dating of low-temperature deformation: Strain-fringe analysis by 40Ar-39Ar laser microprobe. Geology, 31, 219-22.

Smith, M. P. \& Rasmussen, J. A. 2008. Cambrian-Silurian development of the Laurentian margin of the Iapetus Ocean in Greenland and related areas. In: Higgins, A. K., Gilotti, J. A. \& Smith, M. P. (eds). The Greenland Caledonides: Evolution of the northeast margin of Laurentia. Geological Society of America Memoirs, 202, 137-167.

Soper, N. J. 1986. The Newer Granite problem: a geotectonic view. Geological Magazine, 123, 227236.

Soper, N.J. \& England, R.W. 1995, Vendian and Riphean rifting in NW Scotland. Journal of the Geological Society of London, 152, 11-14.

Soper, N.J. \& Harris, A.L. 1997. Report: Highland field workshops 1995-1996. Scottish Journal of Geology, 33, 187-190.

Soper, N. J., Ryan, P. D. \& Dewey, J. F. 1999, Age of the Grampian orogeny in Scotland and Ireland. Journal of the Geological Society of London, 156, 1231-1236.

Soper, N. J., Strachan, R. A., Holdsworth, R. E., Gayer, R. A. \& Greiling, R. O. 1992, Sinistral transpression and the Silurian closure of Iapetus. Journal of the Geological Society of London, 149, 871-880.

Soper, N. J. \&Woodcock, N. H. 2003. The lost Lower Old Red Sandstone of England and Wales: a record of post-Iapetan flexure or Early Devonian transtension? Geological Magazine, 140, 627-647.

Spring, J. S. 1960, The Geology of Knoydart. Ph. D thesis, Imperial College, Unversity of London.

Stephens, W. E. 1992, Spatial, compositional and rheological constraints on the origin of zoning in the Criffell pluton, Scotland. Transactions of the Royal Society of Edinburgh: Earth Sciences, 83, 191-199. 
1763 Stephens, W. E. \& Halliday, A. N. 1984. Geochemical contrasts between late Caledonian granitoid

1764

1765

1766

1767

1768

1769

1770

1771

1772

1773

1774

1775

1776

1777

1778

1779

1780

1781

1782

1783

1784

1785

1786

1787

1788

1789

1790

1791 plutons of northern, central and southern Scotland. Transactions of the Royal Society of Edinburgh: Earth Sciences, 75, 259-273.

Stephenson, D. \& Gould, D. 1995. The Grampian Highlands. British regional geology, HMSO for the British Geological Survey, London.

Stevenson, C. T. E. 2008, A Revised intrusion sequence for the Donegal Batholith: evidence from its aureole in Lettermacaward. Irish Journal of Earth Sciences, 26, 33-43.

Stevenson, C. T. E., Hutton, D. H. W. \& Price, A. R. 2008, The Trawenagh Bay Granite and a new model for the emplacement of the Donegal Batholith. Transactions of the Royal Society of Edinburgh: Earth Sciences, 97, 455-477.

Stewart, A. D. 2002. The later Proterozoic Torridonian rocks of Scotland: their sedimentology, geochemistry and origin. Geological Society Memoir, 24, The Geological Society, London.

Stone, P. 1995, Geology of the Rhinns of Galloway. Memoir of the British Geological Survey, HMSO.

Stone, P. 2014a. A review of geological origins and relationships in the Ballantrae Complex, SW Scotland. Scottish Journal of Geology. 50, 1-25

Stone, P. 2014b. The Southern Uplands Terrane in Scotland - a notional controversy revisited. Scottish Journal of Geology, 50. In press

Stone, P. \& Evans, J. A. 2001. Silurian provenance variation in the Southern Uplands terrane, Scotland, assessed using neodymium isotopes and linked with regional tectonic evolution. Transactions of the Royal Society of Edinburgh: Earth Sciences, 91, 447455

Stone, P., Kimbell, G. S. \& Henney, P. J. 1997. Basement control on the location of strike-slip shear in the Southern Uplands of Scotland. Journal of the Geological Society of London, 154, 141-144.

Storey, C. D. 2008. The Glenelg-Attadale Inlier, NW Scotland, with emphasis on the Precambrian high-pressure metamorphic history and subsequent retrogression: an introduction and review. Scottish Journal of Geology, 44, 1-16. 
1792 Strachan, R.A. \& Evans, J.A. 2008, Structural setting and U-Pb geochronology of the Glen Scaddle

1793

1794

1795

1796

1797

1798

1799

1800

1801

1802

1803

1804

1805

1806

1807

1808

1809

1810

1811

1812

1813

1814

1815

1816

1817

1818

1819

1820

1821

Metagabbro: evidence for polyphase Scandian ductile deformation in the Caledonides of northern Scotland. Geological Magazine, 145, 361-371.

Strachan, R. A., Holdsworth, R. E., Krabbendam, M. \& Alsop, G. I. 2010. The Moine Supergroup of NW Scotland: insights into the analysis of polyorogenic supracrustal sequences. In: Law, R., Butler, R. W. H., Holdsworth, R. E., Krabbendam, M. \& Strachan, R. A. (eds). Continental Tectonics and Mountain Building: The Legacy of Peach and Horne. Geological Society, London, Special Publication, 335, 231-252.

Strachan, R.A., Nutman, A.P. \& Friderichsen, J.D. 1995, SHRIMP U-Pb geochronology and metamorphic history of the Smallefjord sequence, NE Greenland Caledonides. Journal of the Geological Society of London, 152, 779-784.

Stringer, P. \& Treagus, J. E. 1980. Non-axial Planar S $_{1}$ Cleavage in the Hawick Rocks of the Galloway Area, Southern Uplands, Scotland. Journal of Structural Geology, 2, 317331.

Stubblefield, C. J. 1956, Cambrian palaeogeography in Britain. In: Rodgers, J. (ed.) El Sistema Cambrico, su paleogeografia y el problema de su base. Report of the International Geological Congress, Mexico, 20, 1-43.

Suess, E. 1906, The Face of the Earth, 2, Translated by H. B. V. Sollas, Oxford.

Sutton, J. \& Watson, J. V. 1951, The pre-Torridonian metamorphic history of the Loch Torridon and Scourie areas in the North-west Highlands and its bearing on the chronological classification of the Lewisian. Quarterly Journal of the Geological Society of London, 106, 241-307.

Sutton, J. 1980. William Quarrier Kennedy. Biographical Memoirs of Fellows of the Royal Society, 26, 274-303.

Tanner, P. G. W. 2011. Discussion of "The Highland Boundary Fault and the Highland Border Complex” by B. J. Bluck. Scottish Journal of Geology, 46, 113-124

Tanner, P. G. \& Sutherland, S. 2007. The Highland Border Complex, Scotland: a paradox resolved. Journal of the Geological Society, London 164, 111-116.

Tanner, P. W. G. 2007. The role of the Highland Border Ophiolite in the 470 Ma Grampian Event, Scotland. Geological Magazine, 144, 597-602. 
1822 Tanner, P. W. G. 2013. A kinematic model for the Grampian Orogeny, Scotland. In: Corfu, F.,

1823

1824

1825

1826

1827

1828

1829

1830

1831

1832

1833

1834

1835

1836

1837

1838

1839

1840

1841

1842

1843

1844

1845

1846

1847

1848

1849

1850

1851

1852
Gasser, D. \& Chew, D. M. (eds). New perspectives on the Caledonides of Scandinavia and related areas. Geological Society, London, Special Publications, 390, 467-511.

Tanner, P.W.G. \& Evans, J.A. 2003. Late Precambrian U-Pb titanite age for peak regional metamorphism and deformation (Knoydartian orogeny) in the western Moine, Scotland. Journal of the Geological Society of London, 160, 555-564.

Thirlwall, M. F. 1988. Geochronology of late Caledonian magmatism in northern Britain. Journal of the Geological Society of London, 145, 951-967.

Thirlwall, M. F., Stephens, W. E. \& Shand, P. 1989. Calc-alkaline magma-genesis in the Scottish Southern Uplands fore-arc: a Pb-Sr-Nd isotope study. Terra abstracts, 1, 178.

Thomas, P. R. 1979. New evidence for a Central Highland Root Zone. In: Harris, A.L., Holland, C.H. \& Leake, B.E. (eds). The Caledonides of the British Isles - Reviewed. Geological Society, London, Special Publications, 8, 205-211.

Treagus, J. E. 1987. The structural evolution of the Dalradian of the Central Highlands of Scotland. Transactions of the Royal Society of Edinburgh: Earth Sciences, 78, 1-15.

Trewin, N. H. 2002. The geology of Scotland. Geological Society of London, 576 pp.

Trewin, N.H. \& Thirlwall, M.F. 2002. The Old Red Sandstone. In: Trewin, N.H. (ed) The Geology of Scotland, The Geological Society of London, 213-249.

Turnbull, M. J. M., Whitehouse, M. J. \& Moorbath, S. 1996. New isotopic age determinations for the Torridonian, NW Scotland. Journal of the Geological Society of London, 153, 955-964.

Upton, B. G., Aspen, P., Graham, A. \& Chapman, N. A. 1976. Pre-Palaeozoic Basement of the Scottish Midland Valley. Nature, London, 260, 517-518.

van Breemen, O. \& Bluck, B. J. 1981, Episodic granite plutonism in the Scottish Caledonides: Nature, London, 291, 113-117.

van Breemen, O., Pidgeon, R. T. \& Johnson, M. R. W. 1974, Precambrian and Palaeozoic pegmatites in the Moines of northern Scotland: Journal of the Geological Society of London, 130, 493-507.

van Breemen, O., Halliday, A. N., Johnson, M. R. W. \& Bowes, D. R. 1978, Crustal additions in late Precambrian times: In: Bowes, D. R. \& Leake, B. E. (eds), Crustal Evolution in 
1853

1854

1855

1856

1857

1858

1859

1860

1861

1862

1863

1864

1865

1866

1867

1868

1869

1870

1871

1872

1873

1874

1875

1876

1877

1878

1879

1880

1881

1882

Northwestern Britain and Adjacent Regions, Geological Journal Special Issue, 10, 81-106.

Vance, D,, Strachan, R. A. \& Jones, K. A. 1998, Extensional versus compressional settings for metamorphism: garnet chronometry and pressure-temperature-time histories in the Moine Supergroup, northwest Scotland. Geology, 26, 927-930.

Van Staal, C.R., Chew, D.M., Zagorevski, A., McNicoll, V., Hibbard, J., Skulski, T., Escayola, M.P., Castonguay, S. \& Sylvester, P.J. 2013. Evidence of Late Ediacaran hyperextension of the Laurentian Iapetan margin in the Birchy Complex, Baie Verte Peninsula, northwest Newfoundland: implications for the opening of Iapetus, formation of peri-Laurentian microcontinents and Taconic-grampian orogenesis. Geoscience Canada, 40, 94-117.

Van Staal, C.R., Dewey, J.F., MacNiocall, C. and McKerrow, W.S. 1998. The Cambrian-Silurian tectonic evolution of the northern Appalachian and British Caledonides: history of a complex southwest Pacific - type segment of Iapetus. In: Blundell, D.J. \& Scott, A.C. (eds). Lyell: the past is the key to the present. Geological Society, London, Special Publications, 143, 199-242.

Vaughan, A. P. M. 1996, A tectonomagmatic model for the genesis and emplacement of Caledonian calc-alkaline lamprophyres: Journal of the Geological Society of London, 153, 613623.

Viete, D. R., Richards, S. W., Lister, G. S., Oliver, G. J. \& Banks, G. J. 2010. Lithospheric-scale extension during Grampian orogenesis in Scotland. Geological Society, London, Special Publications, 335, 121-160.

Waldron, J. W. F. 2008, Floyd, J. D., Simonetti, A. \& Hearman, L. M., Ancient Laurentian detrital zircon in the closing Iapetus Ocean, Southern Uplands terrane, Scotland: Geology, 36, 527-530.

Waldron, J.W.F., Schofield, D.I., Dufrane, A., Floyd, J.D., Crowley, Q.G., Simonetti, A., Dokken, R.J. \& Pothier, H.D. 2014. Ganderia-Laurentia collision in the Caledonides of Great Britain and Ireland. Journal of the Geological Society of London, 171, 555-569.

Waschbusch, P., Batt, G. \& Beaumont, C. 1998, Subduction zone retreat and recent tectonics of the south island of New Zealand. Tectonics, 17, 267-284. 
1883 Wellings, S. A. 1998, Timing of deformation associated with the syn-tectonic Dawros-

1884

1885

1886

1887

1888

1889

1890

1891

1892

1893

1894

1895

1896

1897

1898

1899

1900

1901

1902

1903

1904

1905

1906

1907

1908

1909

1910

1911 1. Highland Controversy time-line; illustrates the relationship between the 'actors' in one of

1912 the greatest controversies in Scottish geology, the recognition of the Moine Thrust. James Nicol

Currywongaun-Doughruagh Complex, NW Connemara, western Ireland: Journal of the Geological Society of London, 155, 25-37.

Wilson, G. 1953. Mullions and rodding structures in the Moine Series of Scotland. Proceedings of the Geologists' Association, 64, 118-151.

White, A. J. R. \& Chappell, B. W. 1983. Granitoid types and their distribution in the Lachlan Fold Belt, southeastern Australia: In: Roddick, J. A. (ed.) Circum-Pacific Plutonic Terranes. Geological Society of America Memoir, 159, 21-34.

Williams, H. \& Hiscott, R. N. 1987. Definition of the Iapetus rift-drift transition in western Newfoundland. Geology, 15, 1044-1047.

Williams, H. \& Stevens, R. 1974. The ancient continental margin of eastern North America, In: Burk, A.A. \& Drake, C.L. (eds). The geology of continental margins. Springer, Berlin Heidelberg, pp. 781-796.

Winchester, J. A. \& Max, M. D. 1984. Geochemistry and Origins of the Annagh Division of the Precambrian Erris Complex, NW County Mayo, Ireland: Precambrian Research, 25, 397-414.

Woodcock, N. H., Soper, N. J. \& Strachan, R. A. 2007. A Rheic cause for the Acadian deformation in Europe: Journal of the Geological Society of London, 164, 1023-36.

Yardley, B. W. D. 1980. Metamorphism and orogeny in the Irish Dalradian. Journal of the Geological Society of London, 137, 303-309.

Yardley, B. W. D. \& Senior, A. 1982. Basic magmatism in Connemara, Ireland: evidence for a volcanic arc?: Journal of the Geological Society of London, 139, 67-70.

Zagorevski, A, Van Breemen, O. \& G. Jenner 2007. The Notre Dame arc and the Taconic orogeny in Newfoundland, Geological Society of America Memoirs, 200, 511-552.

Figure captions. 
1913 first recognized the dislocation along the Moine Thrust Zone. For twenty years, Nicol was

1914 vilified as the lone proponent of a Moine Dislocation” until Callaway and Lapworth showed, by

1915 meticulous mapping, that the Moine rocks are thrust upon the foreland, confirmed, a few years

1916 later, by Peach and Horne and their colleagues.

1917

1918 2. A Simplified Tectonic Map of Scotland and Ireland north of the Iapetus Suture

1919 (simplified from British Geological Survey (1996). B. Restoration to the late Silurian by

1920 removing 500 kilometers of sinistral displacement on the Great Glen Fault, the principal

1921 evidence for which is the absence of Scandian deformation in the Dalradian. BA-Ballantrae,

1922 BU-Bute, CBS-Clew Bay Suture, CIT-Colonsay-Islay Terrane, CT-Connemara Terrane, DP-

1923 Deer Park, HBF-Highland Boundary Fault, GGF-Great Glen Fault, IS-Iapetus Suture, LDT-

1924 Longford/Down Terrane, LST-Loch Skerrols Thrust, MVT-Midland Valley Terrane, OBF-

1925 Orlock Bridge Fault, OMT-Ox Mountains Terrane, PPT-PortPatrick Terrane, SCT-South

1926 Connemara Terrane, SH-Shetland, SMT-South Mayo Terrane, SUF-Southern Uplands Fault,

1927 SUT-Southern Uplands Terrane, TY-Tyrone. Ornament: oblique fine lines-early Ordovician

1928 (Grampian) deformation, horizontal fine lines-mid-Silurian (Scandian) deformation, heavy

1929 vertical lines, end- Silurian (Erian) deformation, fine vertical lines-Ordovician/Silurian

1930 subduction-accretion deformation.

1931

1932

1933 3. Knoydartian, Grampian, Mayoian, Scandian, Erian, and Acadian events and their

1934 associated facies and structures.

1935

1936 4. Simplified geological map of the Moine Supergroup and northwestern Caledonian

1937 foreland of the Northern Highlands of Scotland (modified from Strachan et al. 2010); inset

1938 shows location on a smaller scale. Abbreviations as follows, from north to south: LE, Loch

1939 Eriboll; T, Tongue; MT, Moine Thrust; SKT, Skinsdale Thrust; NT, Naver Thrust; ST, Swordly

1940 Thrust; LB, Loch Borolan; D, Durcha; OB, Oykell Bridge; CCG, Carn Chuinneag Granite; F,

1941 Fannich; IBG, Inchbae Augen Gneiss; CG, Carn Gorm; SC, Scardroy; SBT, Sgurr Beag Thrust;

1942 LM, Loch Monar; GU, Glen Urquhart; Dr, Druimnadrochit; Av, Avernish; G, Glenelg; GD, Glen

1943 Doe Granitic Gneiss; FAGG, Fort Augustus Granitic Gneiss; K, Kinlochourn; LA, Loch Arkaig 
1944 Granitic Gneiss; WHGG, West Highland Granitic Gneiss; SB, Sgurr Beag; L, Lochailort; LE, 1945 Loch Eilt; GF, Glenfinnan; Ar, Ardnish; LEL, Loch Eil; GSM, Glen Scaddle Metagabbro; SD,

1946 Sgurr Dhomhnuill Augen Gneiss; AGG, Ardgour Granitic Gneiss; AD, Ardnamurchan; LS, Loch 1947 Sunart; SM, Sound of Mull; RM, Ross of Mull.

1948

1949

1950 5. Part of the Rodinian supercontinent at $1.0 \mathrm{Ga}$ in present day Laurentian coordinates with 1951 Baltica positioned as in Cawood et al. (2010) and with Kalahari and part of Antarctica as in 1952 Loewy et al. (2011). Major cratons: LAU-Laurentia; BAL - Baltica; AM - Amazonia; K 1953 KalahariSmaller features (clockwise from top); GRN - Greenland; VO - Valhalla orogen; BI 1954 fragments of the British Isles (see inset); SR-southern Rockall Bank; N - Newfoundland (Long 1955 Range Peninsula); AQ - Arequipa massif; SO Sunsas orogen; AF - Antofalla massif; O 1956 Oaxacia terrane; WP - western Pampeanas; CU - Cuyania terrane (greater Argentine Pre1957 Cordillera); NN - Namaqua-Natal orogen; G - Grunehogna terrane (Dronning Maud Land, 1958 Antarctica); M - Maud orogen (Heimefrontfjella, Antarctica); C - Coats Land, Antarctica. Inset: 1959 enlargement of area between Greenland and Baltica. NWF - Northwest Foreland (Laurentian); 1960 NH Northern Highlands (? Grenvillian, see text); GH - Grampian Highlands (? Grenvillian, see 1961 text); WI - western Ireland (Grenvillian, see text); MV - Midland Valley (? Grenvillian, see

1962 text). Speckled ornament-Grenvillian (GR) of Laurentia and presumed 1.0 Ga equivalents (see 1963 text)

1964

1965 6. Stratigraphy of Southern Uplands (from Mange, et al. 2005) showing the diachronous 1966 southward progression of the beginning and end of greywacke turbidites.

1967 1968

$19697 . \quad$ Caledonian Newer Granites of Scotland and Ireland 


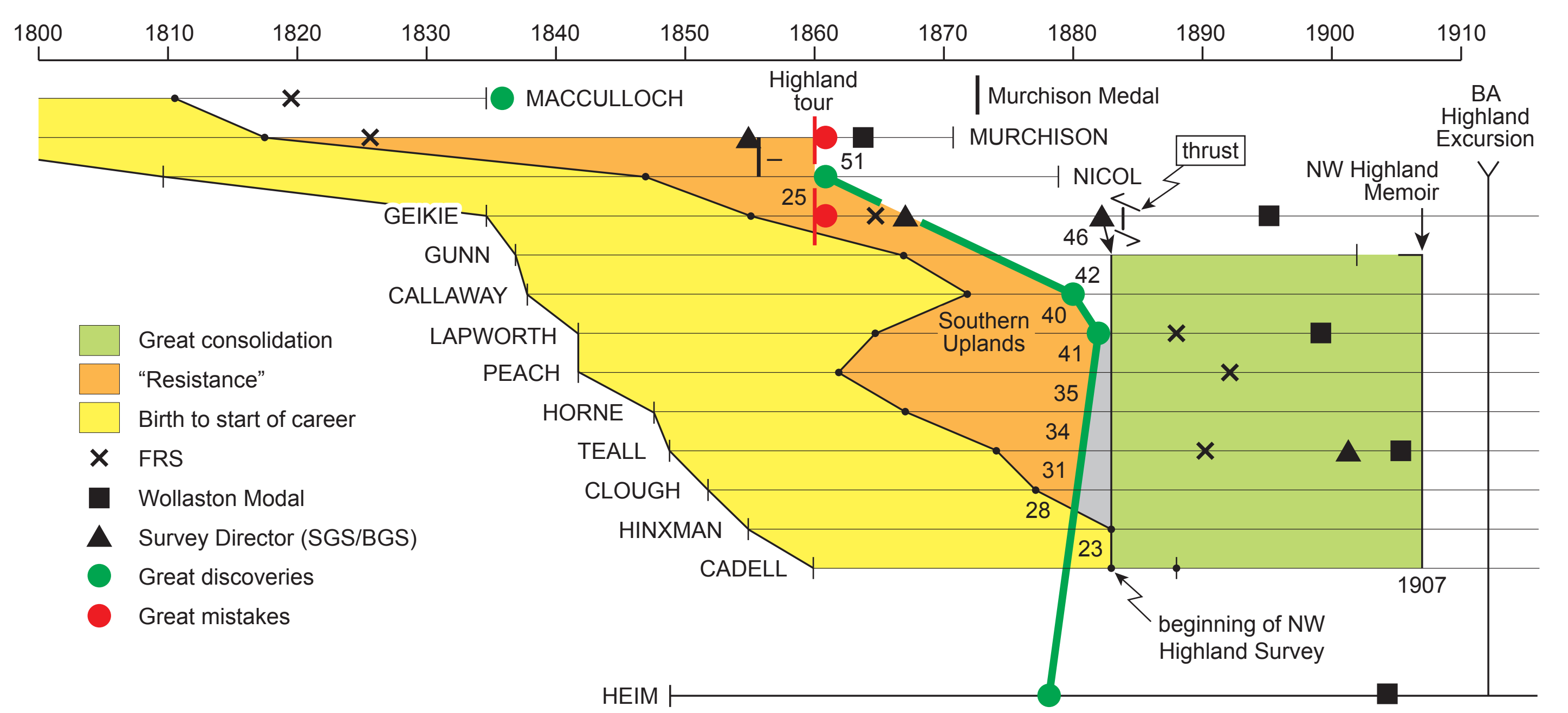




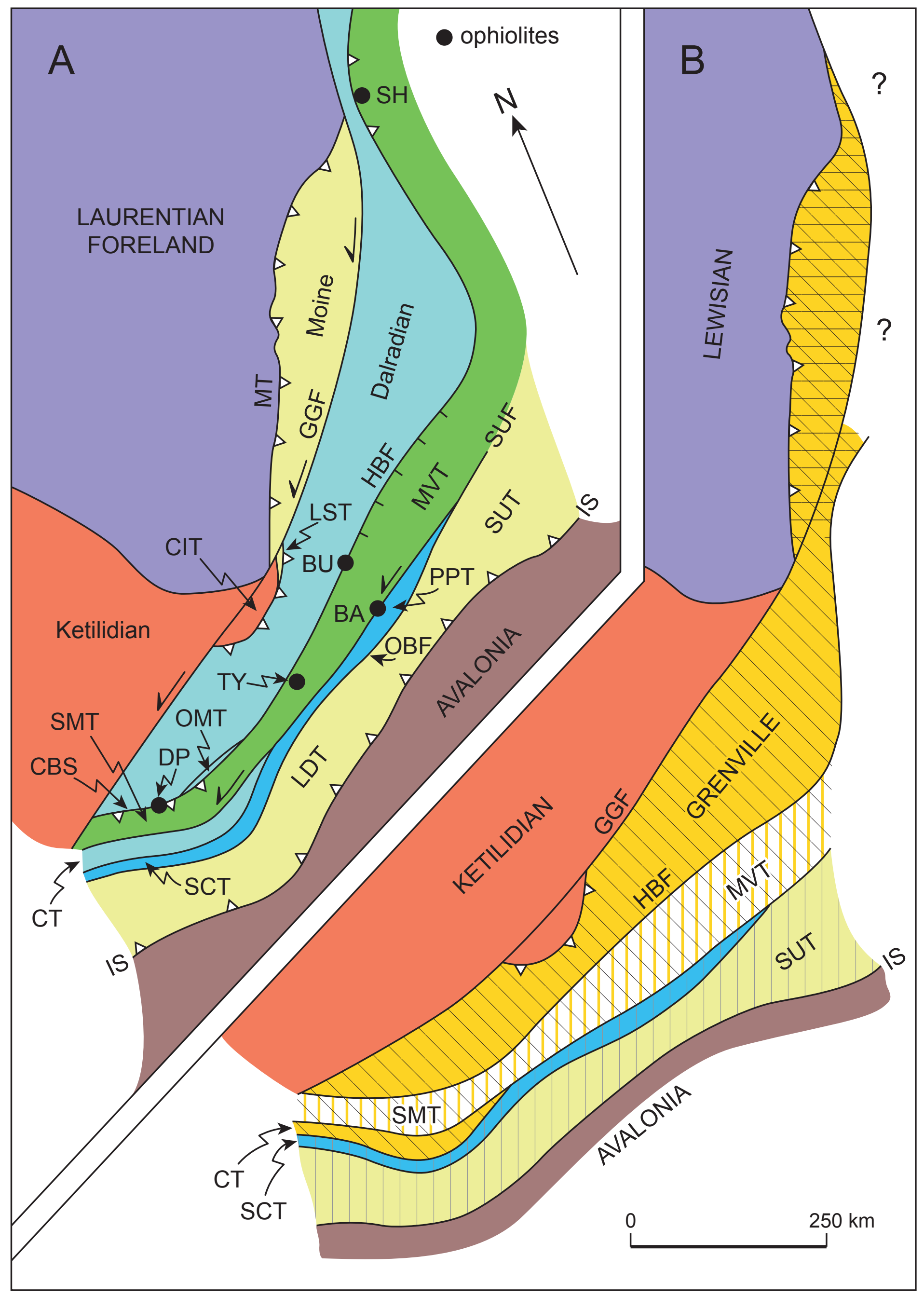




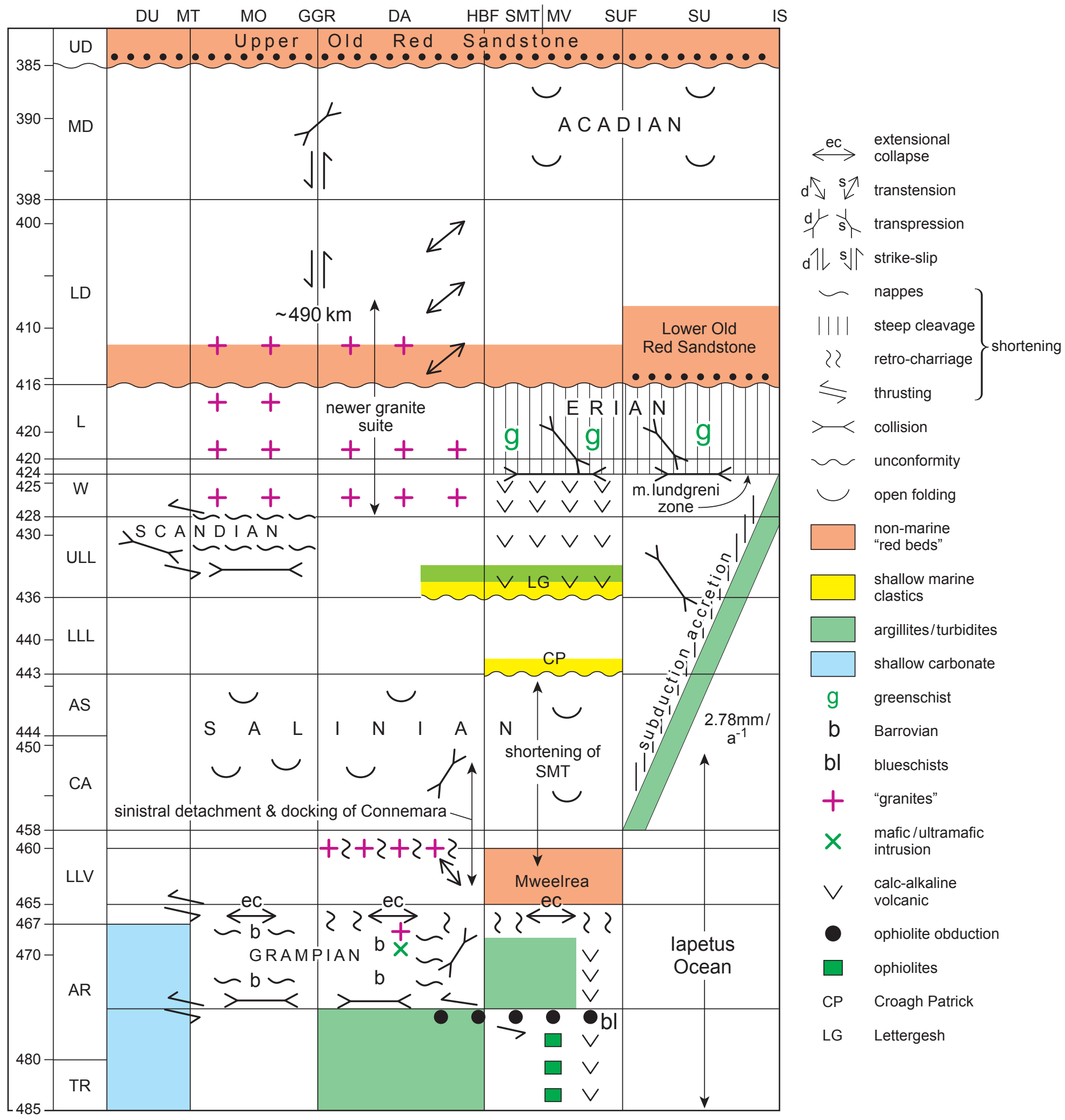




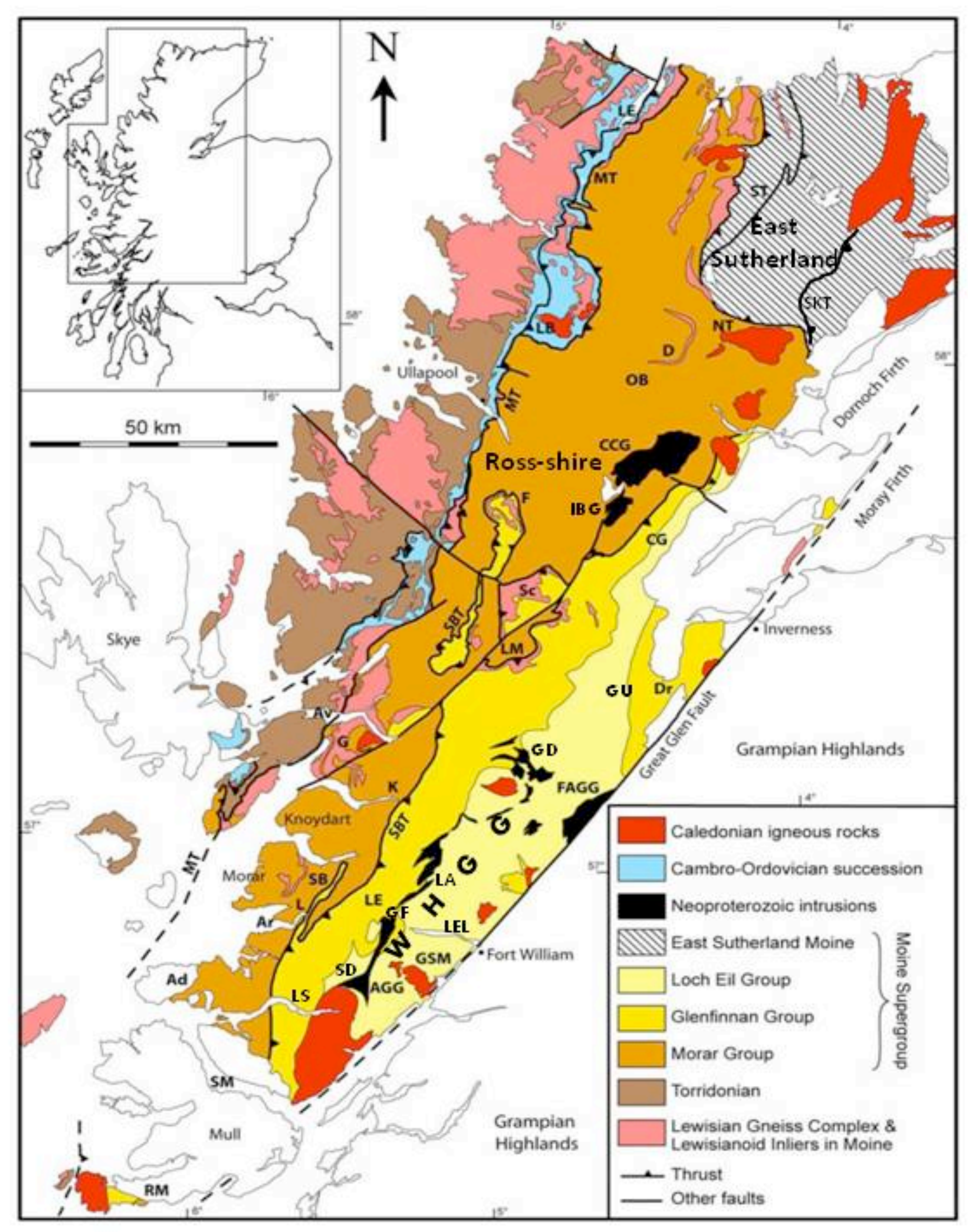




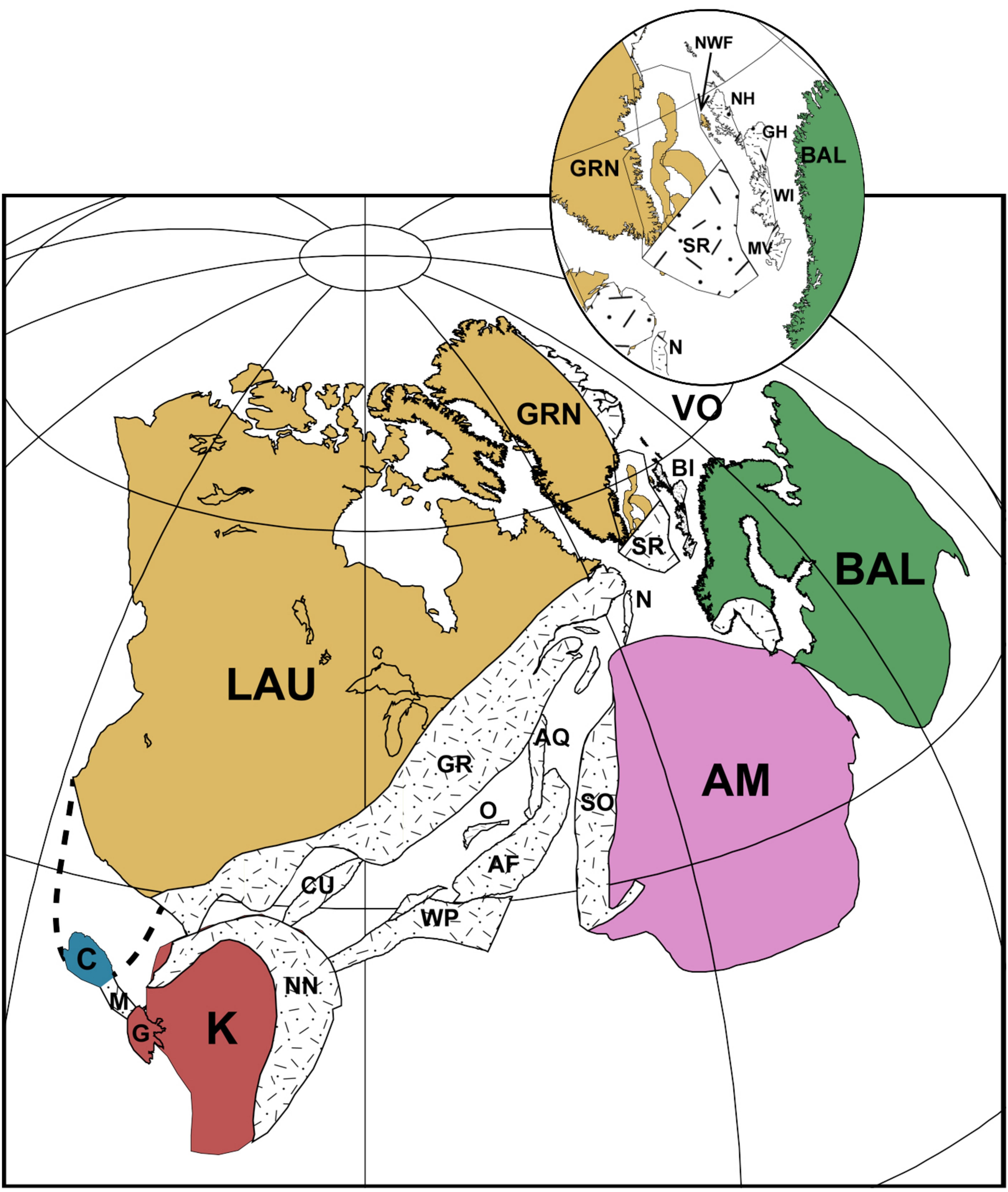




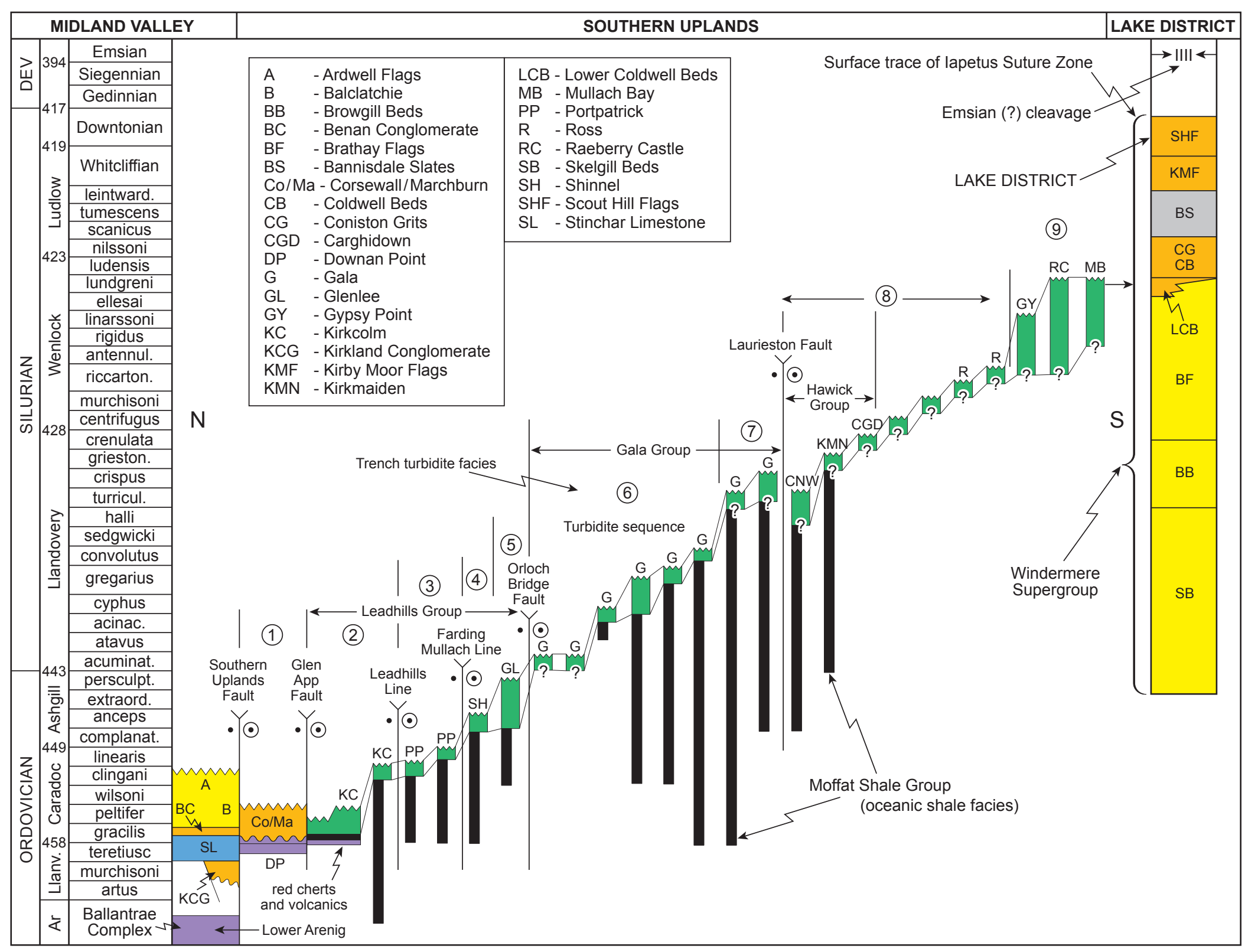


1. Ben Loyal. 2. Strath Halladle. 3. Loch Barralan. 4. Loch Ailsh. 5. Helmsdale. 6. Rogart. 7. Carn Chuinneag. 8. Fearn. 9. Migdale. 10. Ratagain. 11. Cluanie. 12. Glendessary. 13. Strontian. 14. Ross of Mull. 15. Abriachan. 16. Moy. 17. Ardclach. 18. Foyers. 19. Allt Crom. 20. Corrieyairack. 21. Nevis. 22. Strath Ossian. 23. Moor of Rannoch. 24. Ballachulish. 25. Etive. 26. Loch Melford. 27. Strichen. 28. Grantown. 29. Ben Rinnes. 30. Ardlethen. 31. Peterhead. 32. Monadliath. 33. Cairngorm. 34. Lochnager. 35. Aberdeen granites including Skeen and Hill of Fare. 36. Bennachie. 37. Glen Tilt. 28. Mt. Battoch. 39. Comrie. 40. Garabal Hill. 41. Arrochar. 42. Distinkhorn. 43. Spango Water. 44. Cairnsmore of Cairsphairn. 45. Loch Doon. 46. Cairnsmore Fleet. 47. Criffel Dalbeattie. 48. Rosses, trawenagh Bay \& Torr. 49. Fanad. 50. Ardara. 51. Main Donegal. 52. Barnesmore. 53. Ox Mountains. 54. Newry. 55. Corvock. 56. Omey. 57. Roundstone 58. Galway 59. Carna. 60. Leinster.

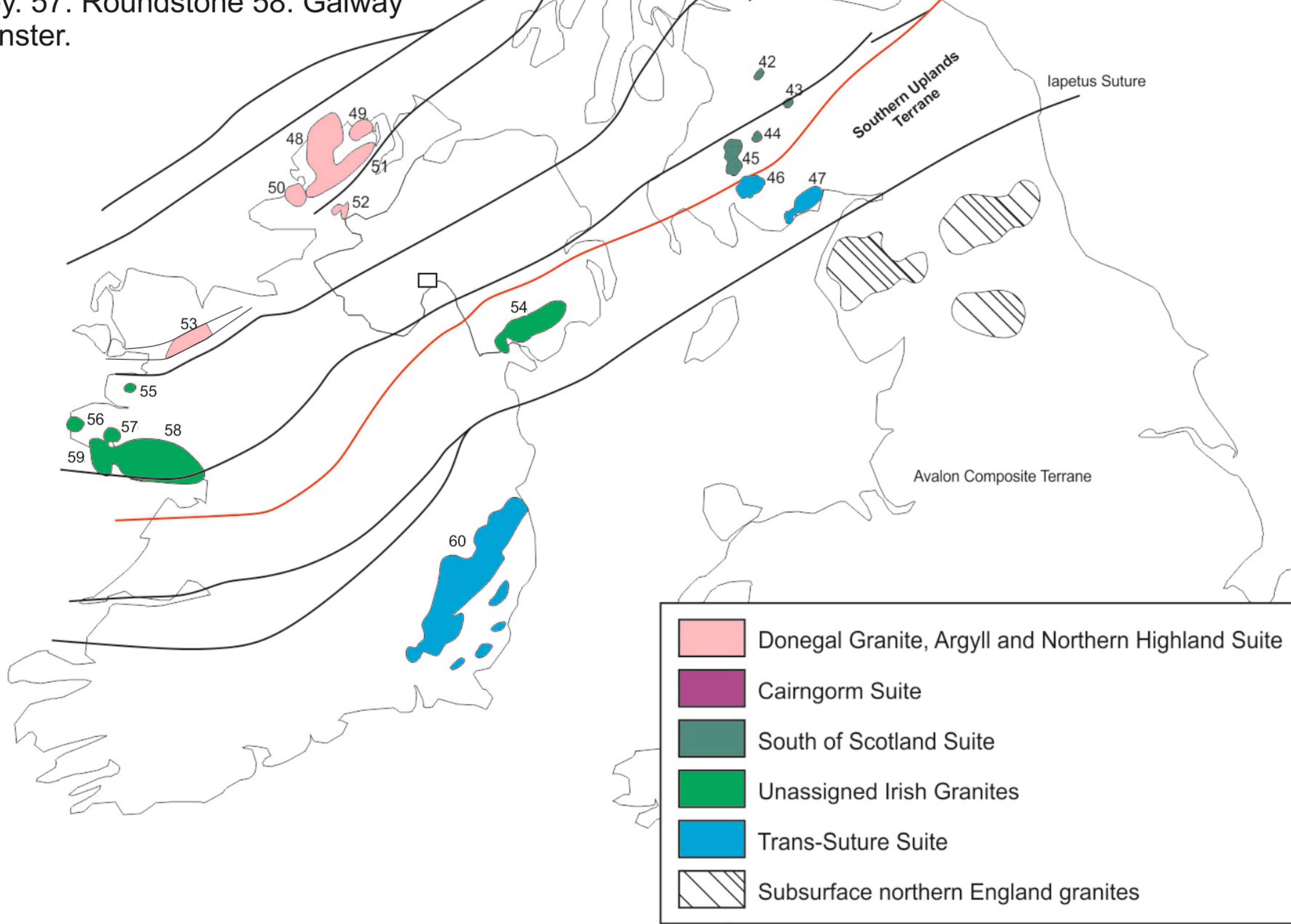

